\title{
Synthesis and Evaluation of Topoisomerase I Inhibitors Possessing the 5,13-Dihydro-6H-benzo[6,7]indolo[3,2-c]quinolin-6-one Scaffold
}

Tsutomu Fukuda, ${ }^{\mathrm{a},}$ " Yuri Matsuo, ${ }^{\mathrm{a}}$ Fuyuki Matsuoka, ${ }^{\mathrm{a}}$ Naoki Yoshioka, ${ }^{\mathrm{a}}$ Gen Onodera, ${ }^{\mathrm{a}}$ Masanari Kimura, ${ }^{a}$ Fumito Ishibashi, ${ }^{b}$ and Masatomo Iwao ${ }^{\mathrm{a}}$

${ }^{a}$ Division of Chemistry and Materials Science, Graduate School of Engineering, Nagasaki University, 1-14 Bunkyo-machi, Nagasaki 852-8521, Japan ${ }^{b}$ Division of Marine Life Science and Biochemistry, Graduate School of Fisheries and Environmental Sciences, Nagasaki University,

1-14 Bunkyo-machi, Nagasaki 852-8521, Japan

\section{List of Contents}

${ }^{1} \mathrm{H}$ and ${ }^{13} \mathrm{C}$ NMR spectra

Chemosensitivity patterns of BIQs 6, 20a, and 20c against the JFCR39 panel and the results of COMPARE analyses 


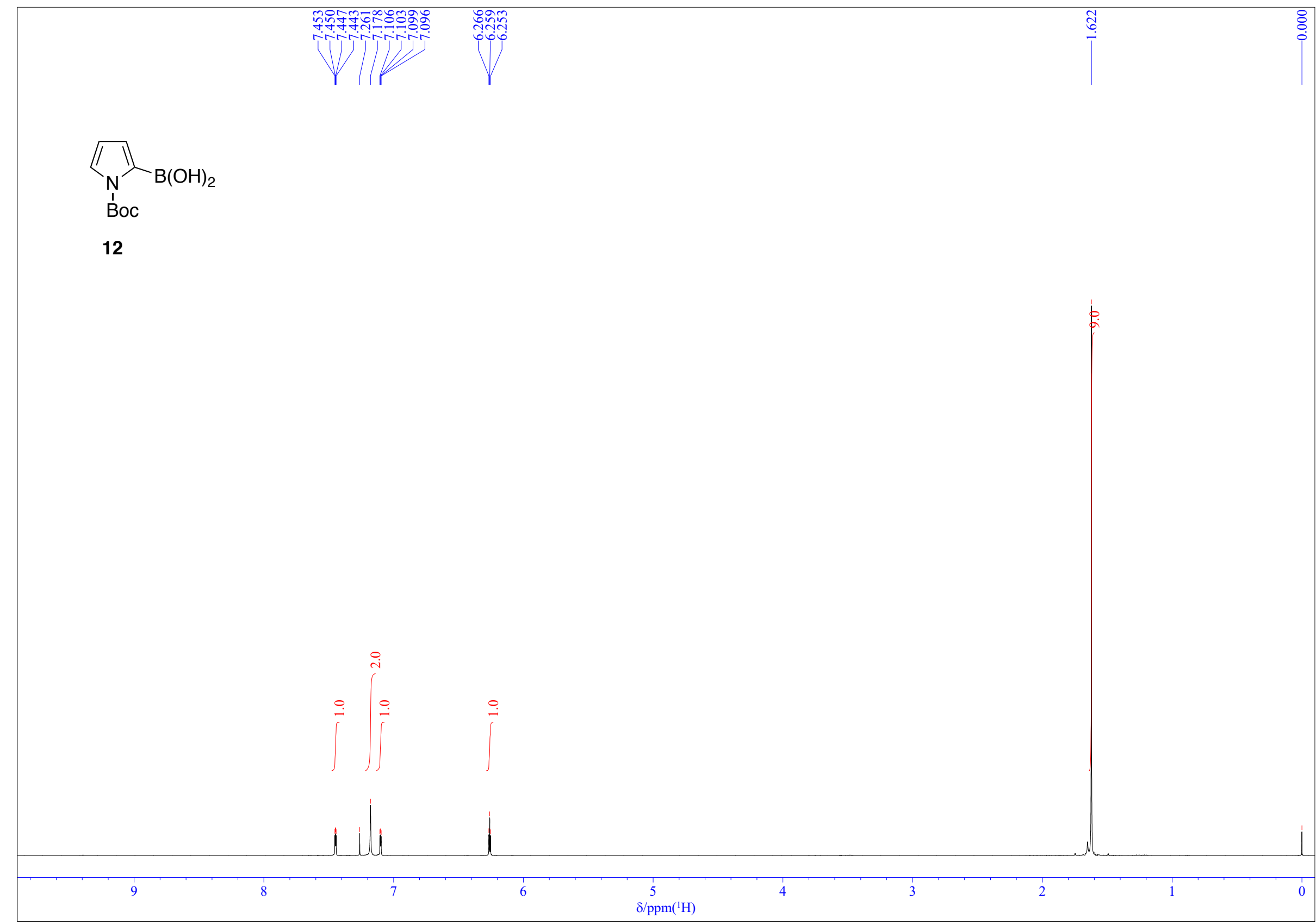

Figure S1. ${ }^{1} \mathrm{H}$ NMR spectrum of compound $12\left(500 \mathrm{MHz}, \mathrm{CDCl}_{3}\right)$. 


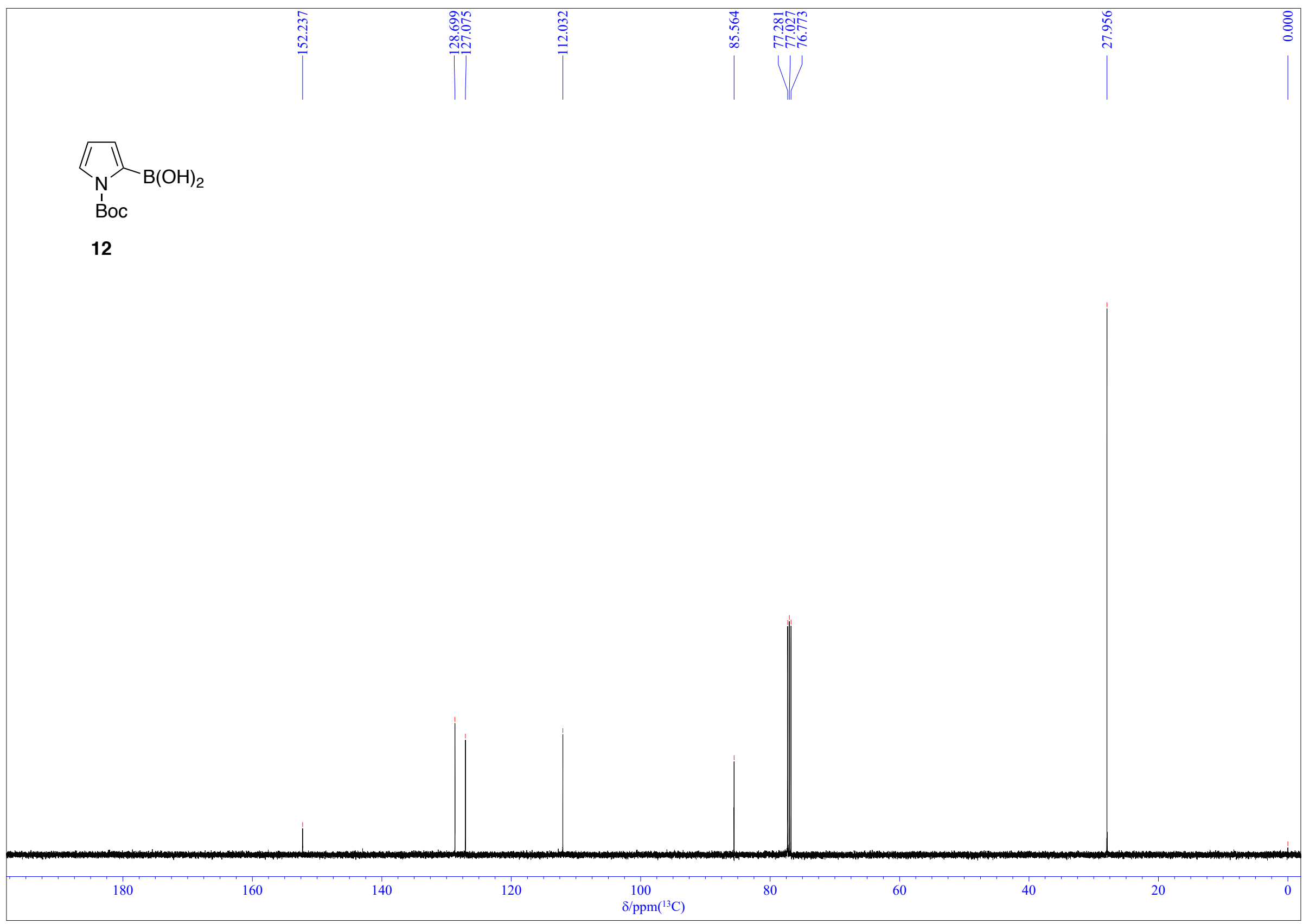

Figure S2. ${ }^{13} \mathrm{C}$ NMR spectrum of compound $12\left(126 \mathrm{MHz}, \mathrm{CDCl}_{3}\right)$. 


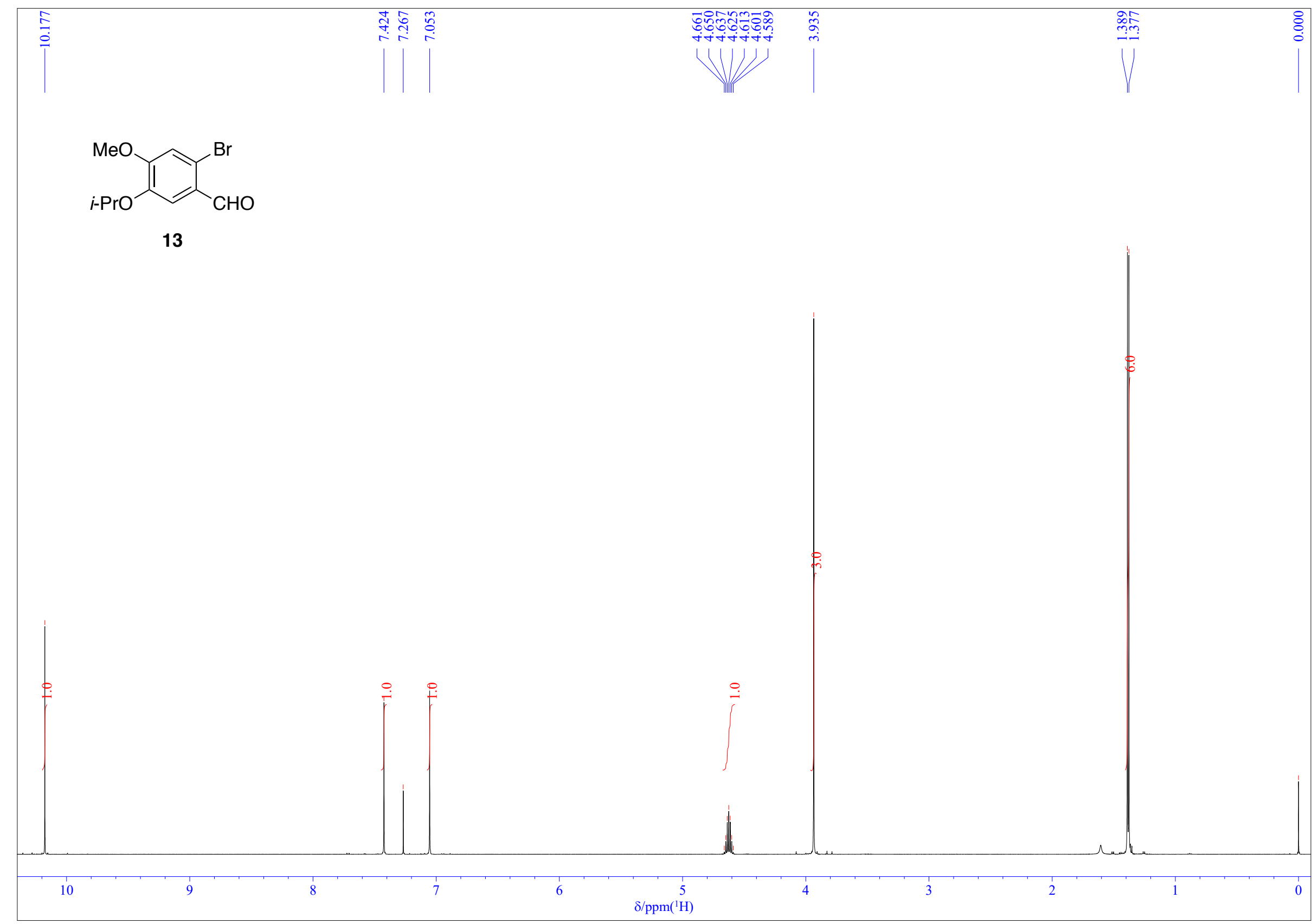

Figure S3. ${ }^{1} \mathrm{H}$ NMR spectrum of compound $13\left(500 \mathrm{MHz}, \mathrm{CDCl}_{3}\right)$. 


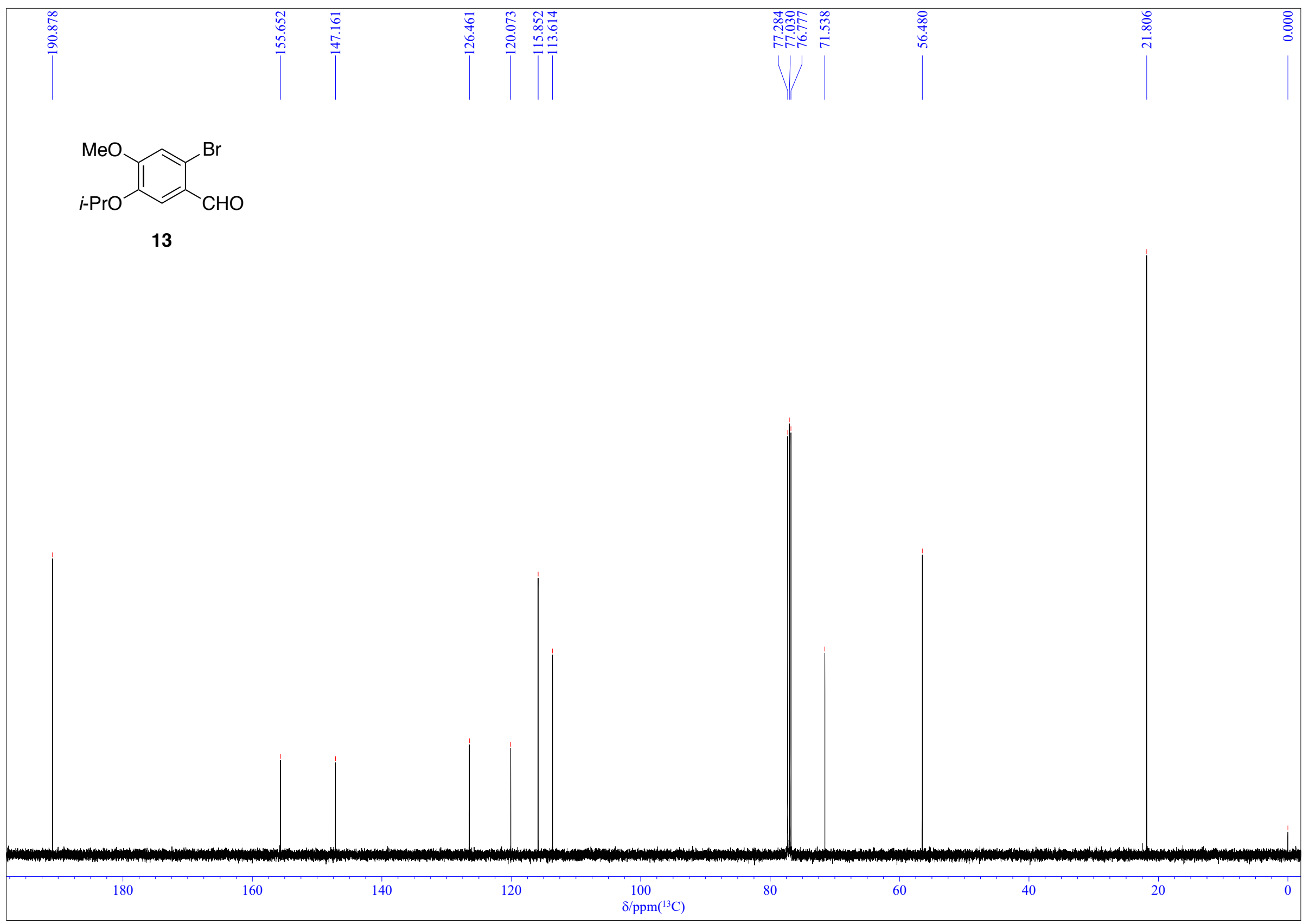

Figure S4. ${ }^{13} \mathrm{C}$ NMR spectrum of compound $\mathbf{1 3}\left(126 \mathrm{MHz}, \mathrm{CDCl}_{3}\right)$. 


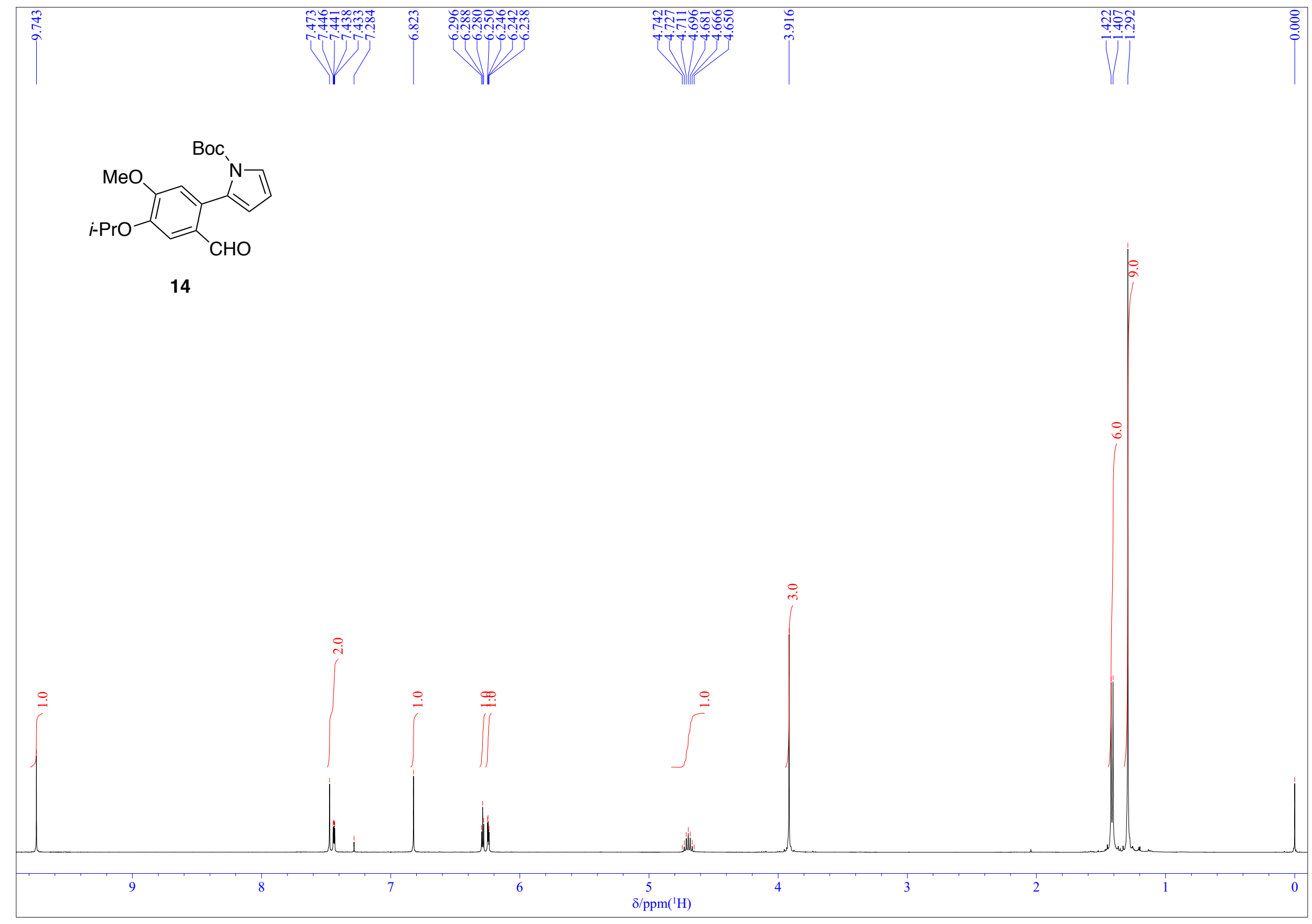

Figure S5. ${ }^{1} \mathrm{H}$ NMR spectrum of compound 14 (400 MHz, $\mathrm{CDCl}_{3}$ ). 


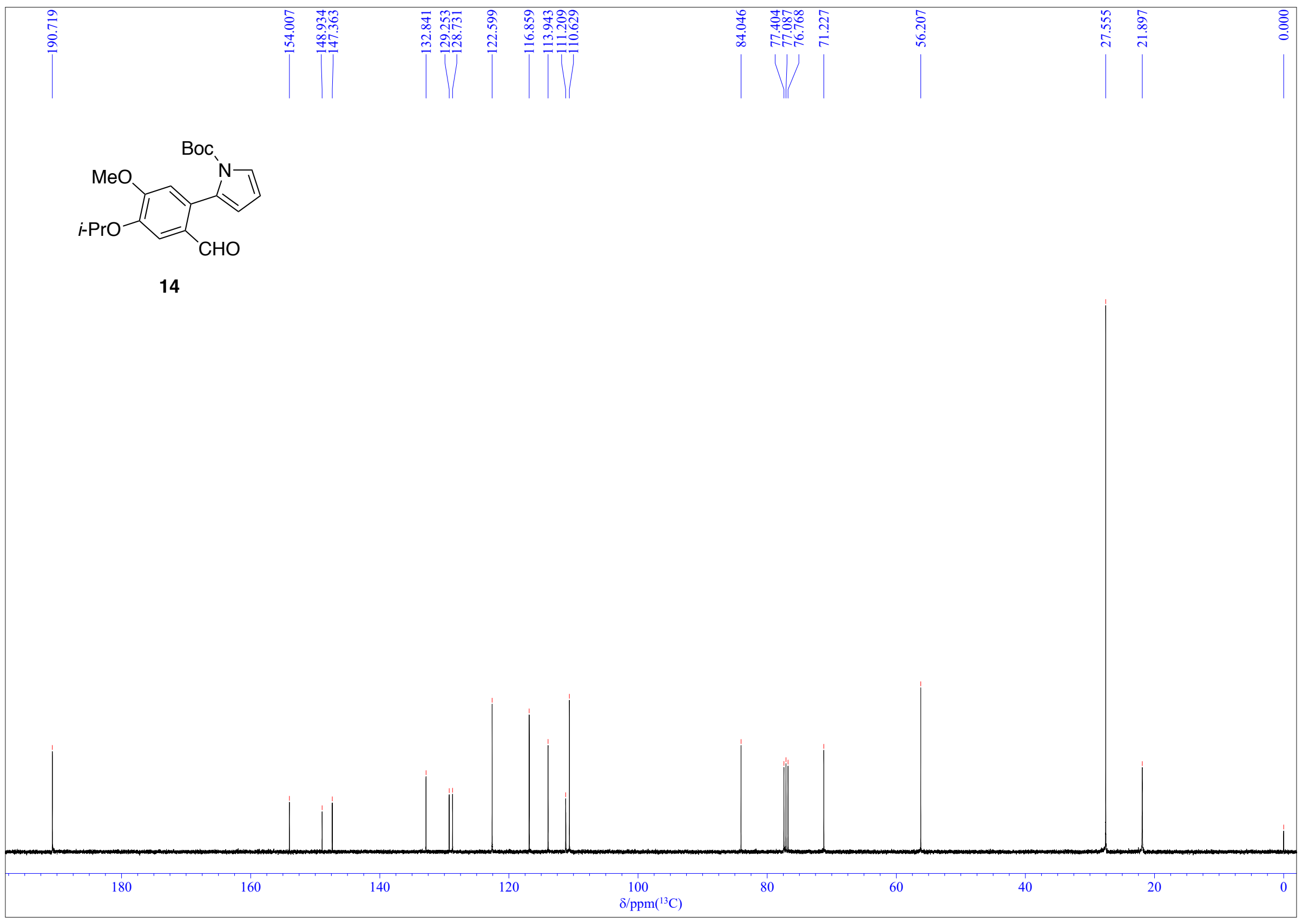

Figure S6. ${ }^{13} \mathrm{C}$ NMR spectrum of compound $14\left(100 \mathrm{MHz}, \mathrm{CDCl}_{3}\right)$. 


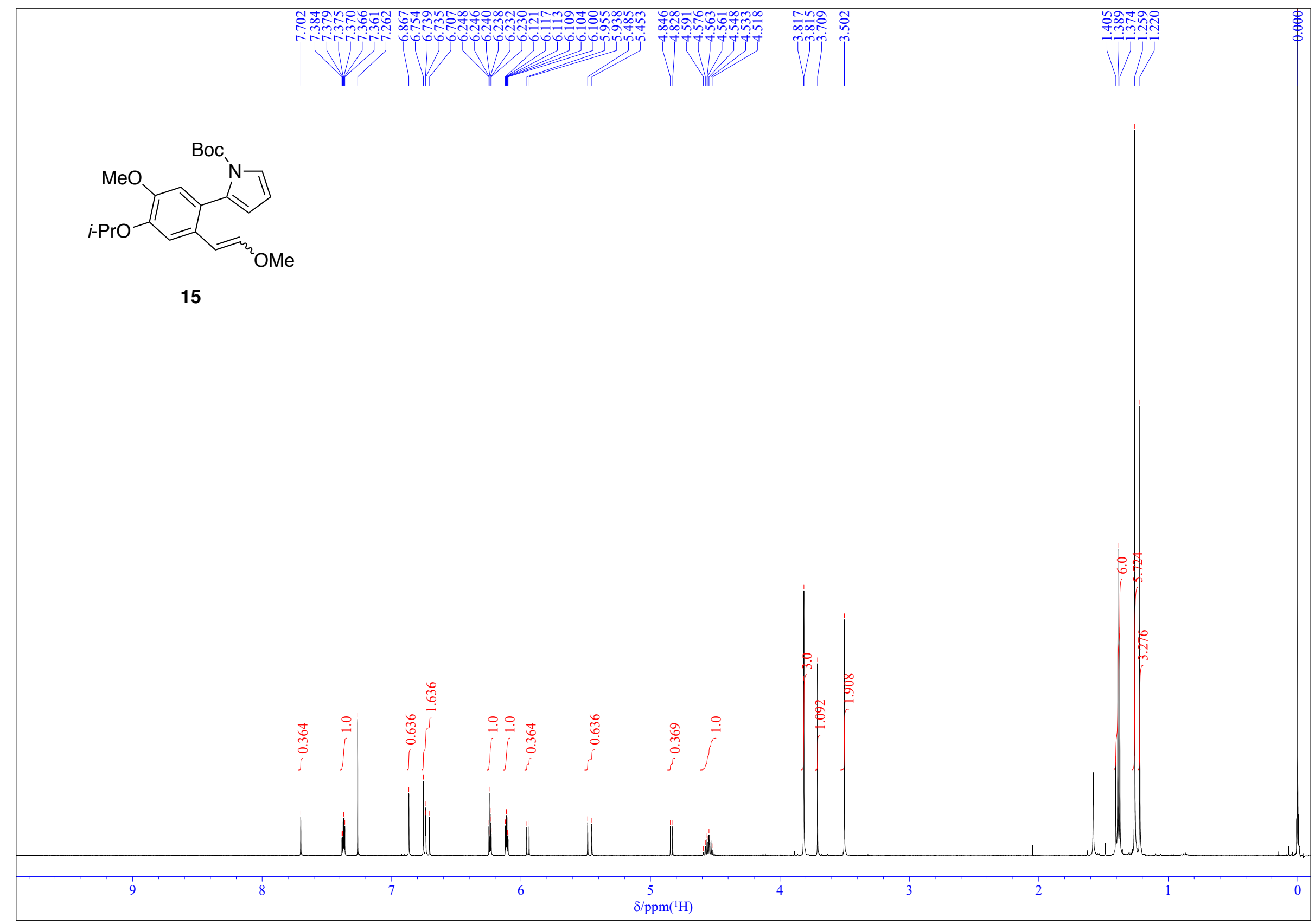

Figure S7. ${ }^{1} \mathrm{H}$ NMR spectrum of compound 15 (400 MHz, $\mathrm{CDCl}_{3}$ ). 


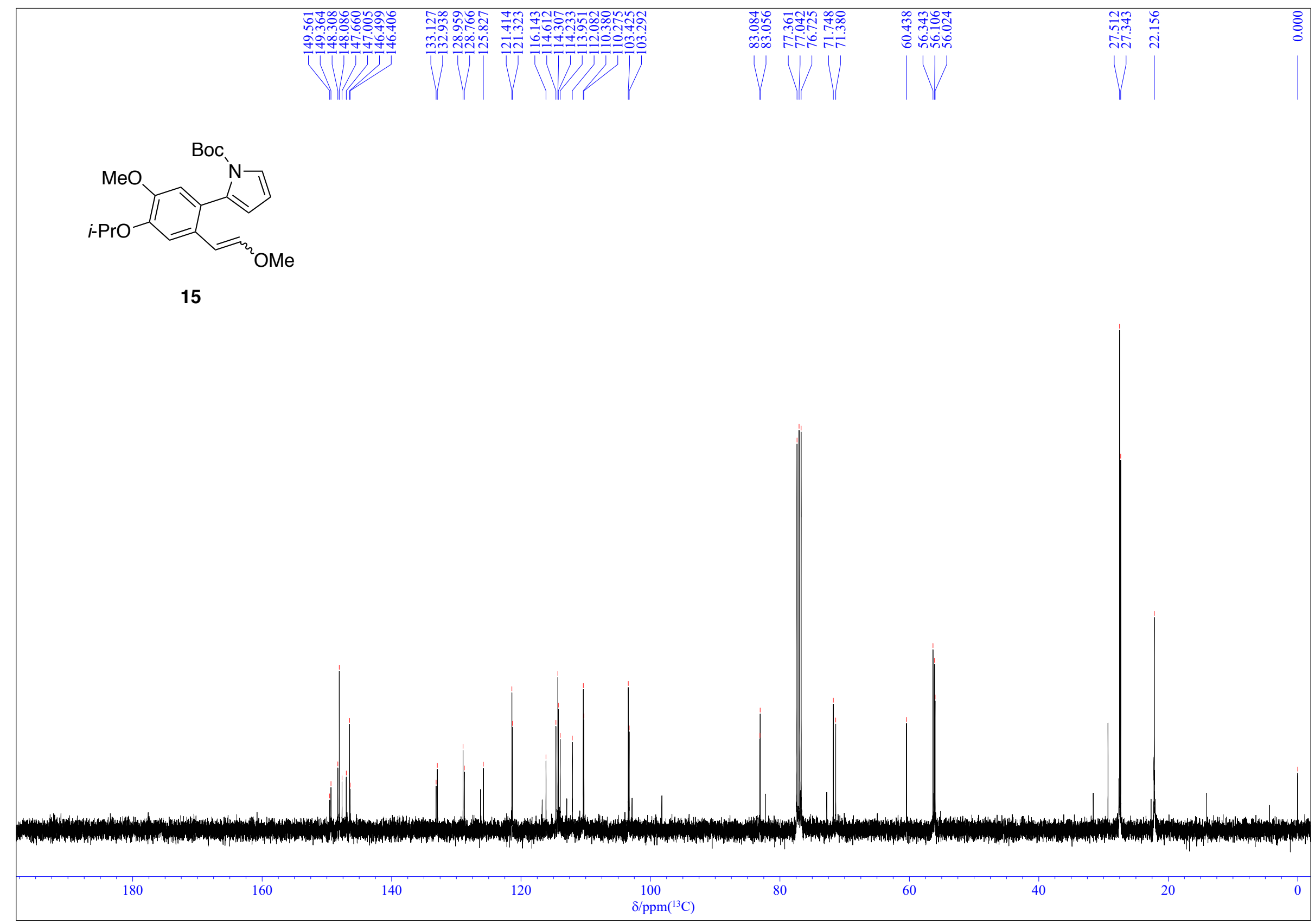

Figure S8. ${ }^{13} \mathrm{C}$ NMR spectrum of compound $15\left(100 \mathrm{MHz}, \mathrm{CDCl}_{3}\right)$. 


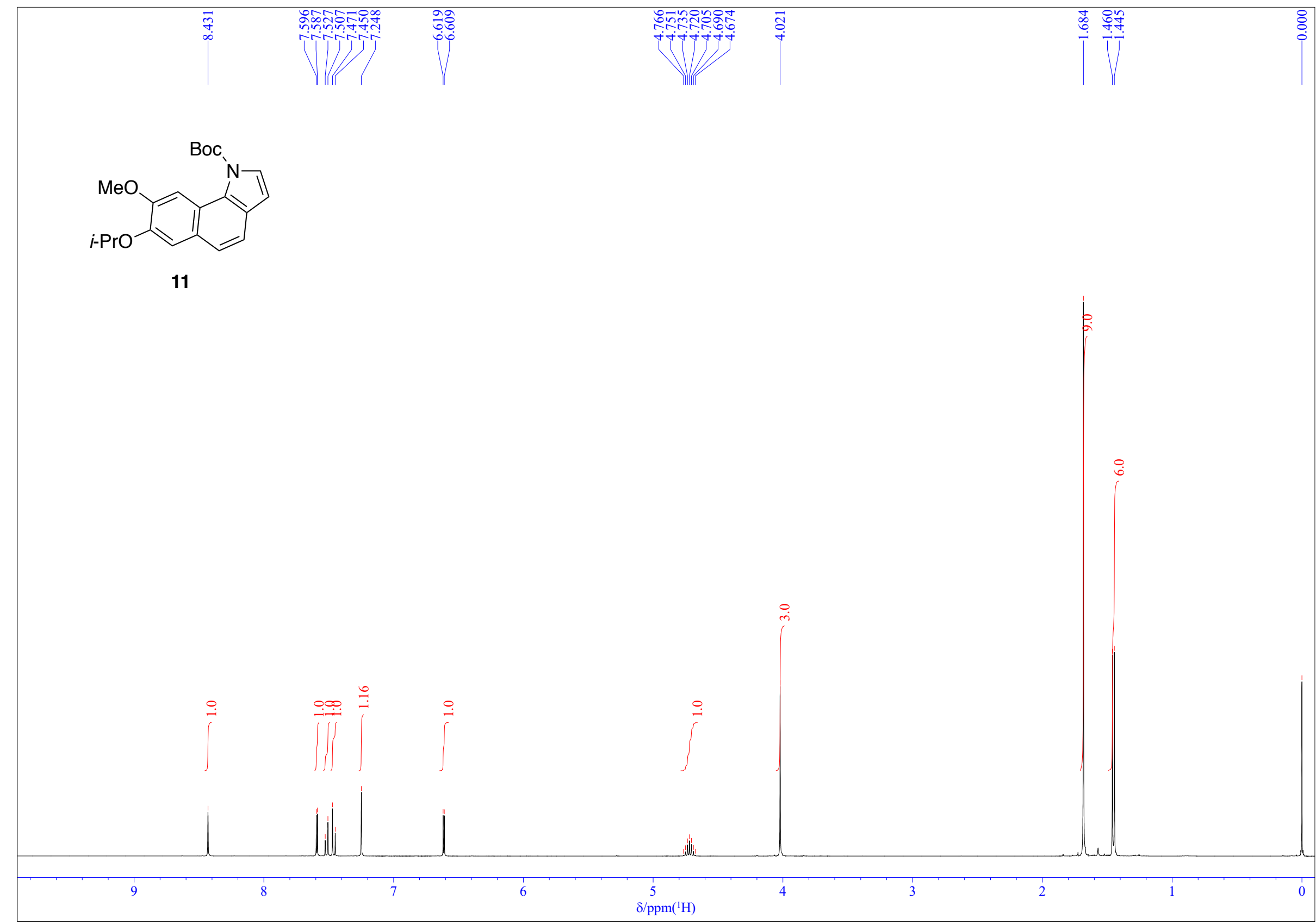

Figure S9. ${ }^{1} \mathrm{H}$ NMR spectrum of compound $11\left(400 \mathrm{MHz}, \mathrm{CDCl}_{3}\right)$. 


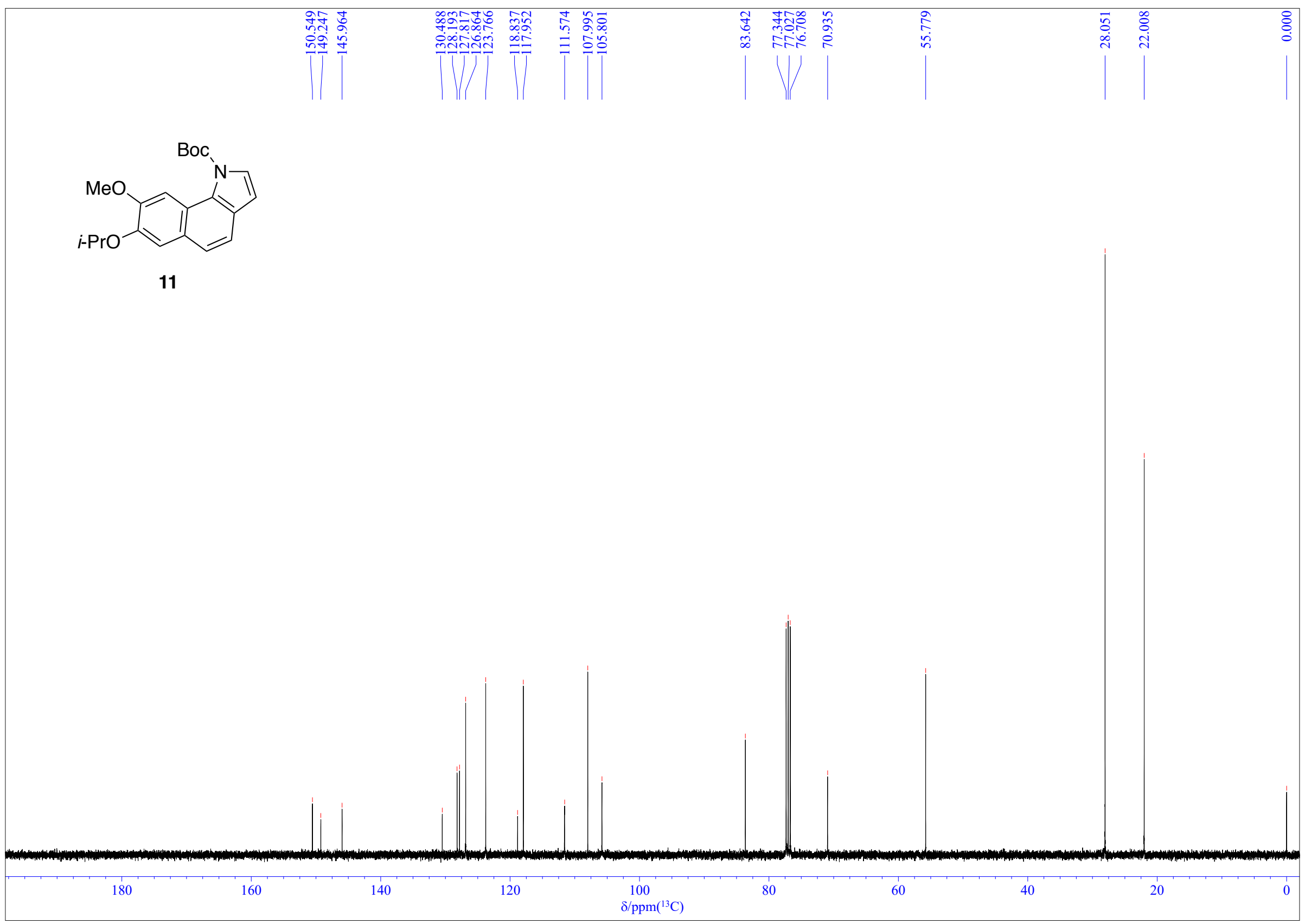

Figure S10. ${ }^{13} \mathrm{C}$ NMR spectrum of compound $11\left(100 \mathrm{MHz}, \mathrm{CDCl}_{3}\right)$. 


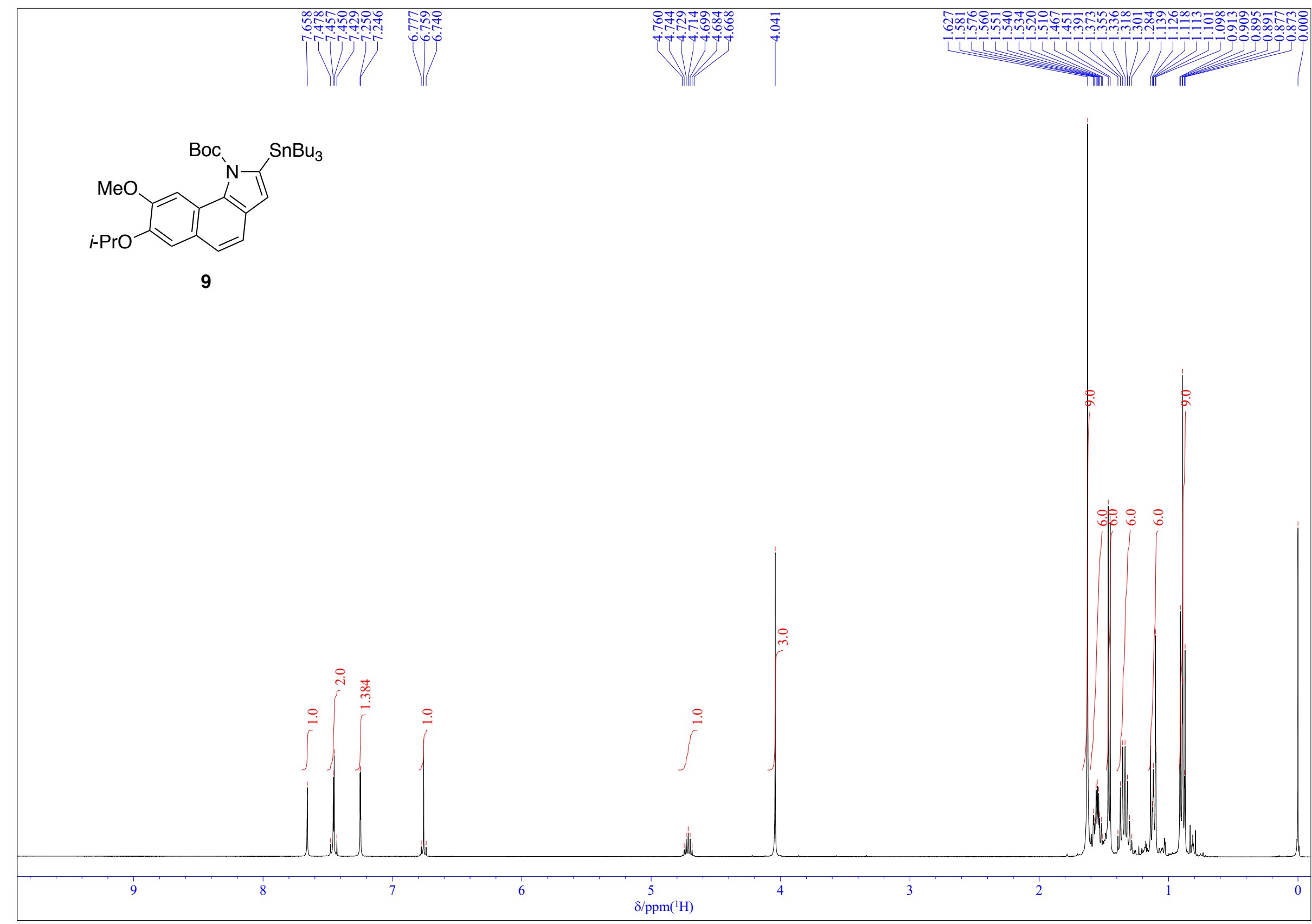

Figure S11. ${ }^{1} \mathrm{H}$ NMR spectrum of compound $9\left(400 \mathrm{MHz}, \mathrm{CDCl}_{3}\right)$. 


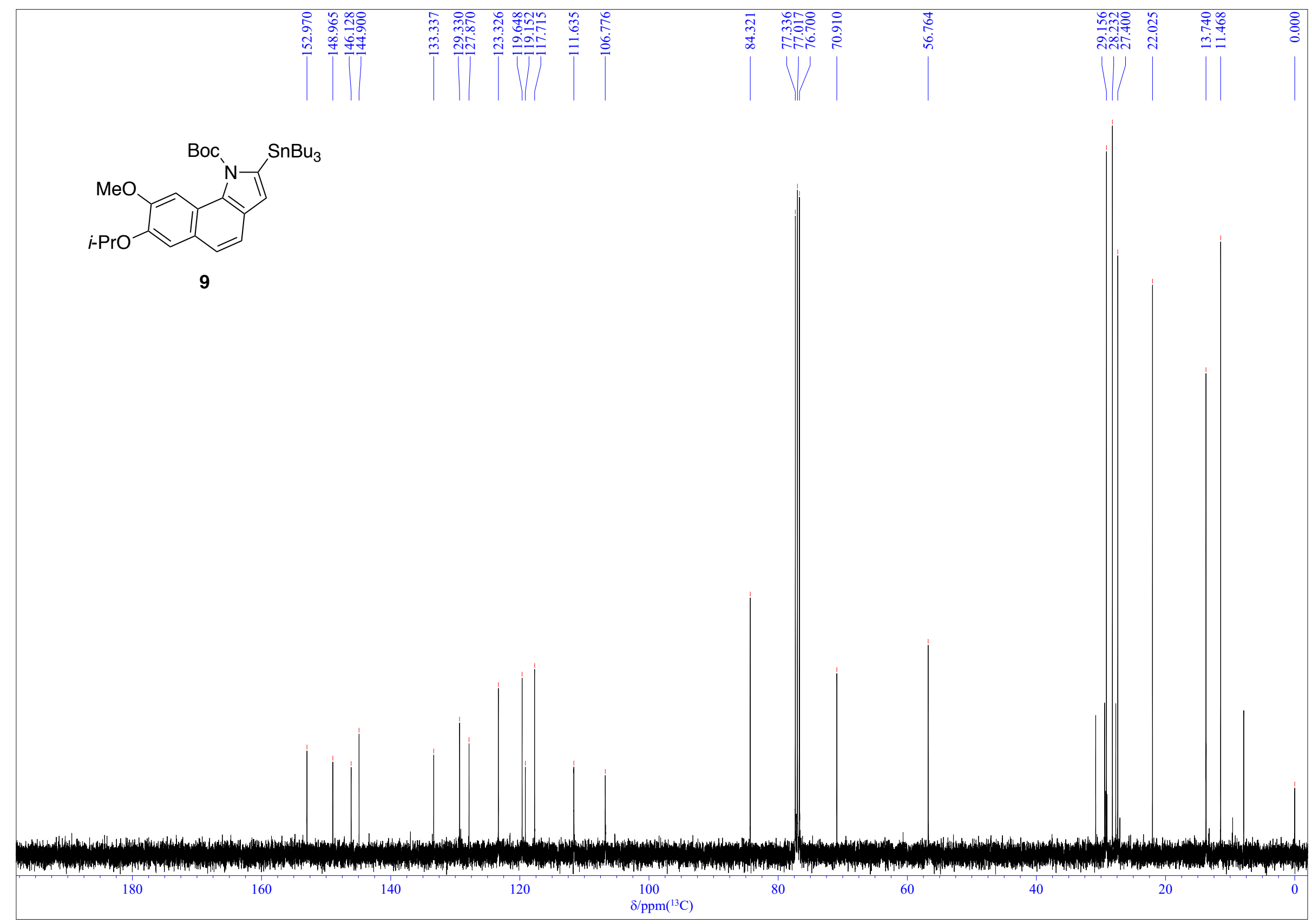

Figure S12. ${ }^{13} \mathrm{C}$ NMR spectrum of compound $9\left(100 \mathrm{MHz}, \mathrm{CDCl}_{3}\right)$. 


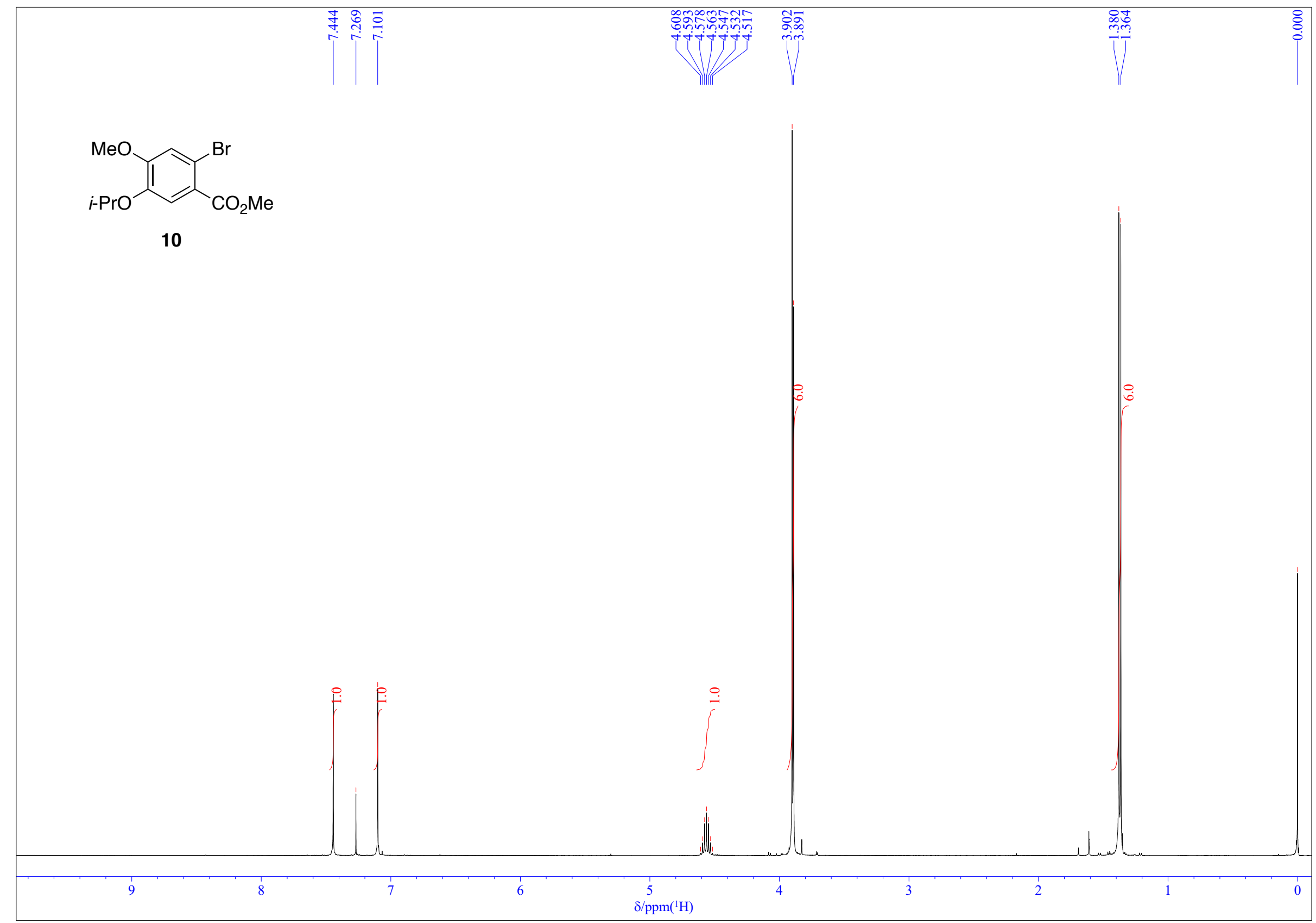

Figure S13. ${ }^{1} \mathrm{H}$ NMR spectrum of compound $10\left(400 \mathrm{MHz}, \mathrm{CDCl}_{3}\right)$. 


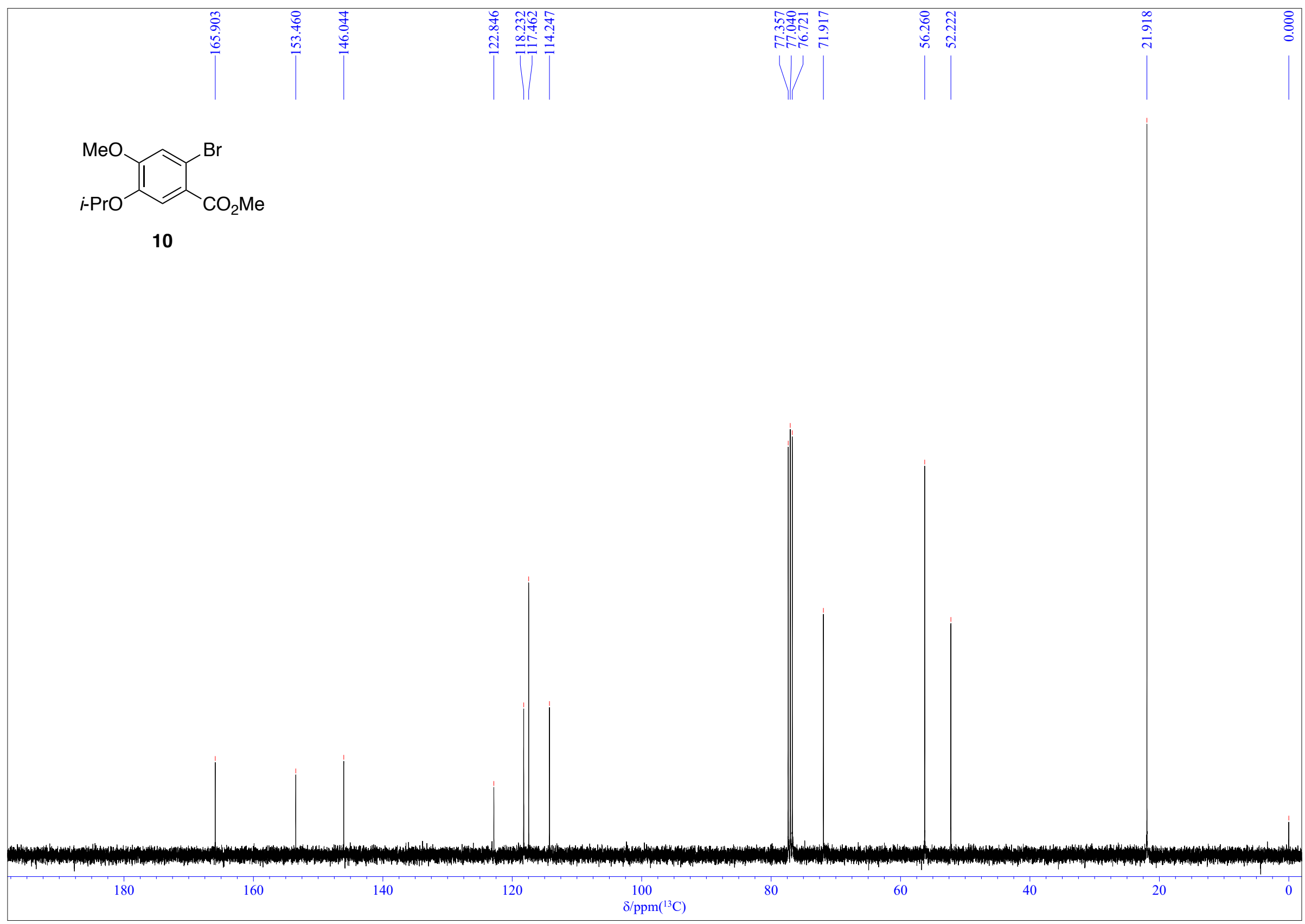

Figure S14. ${ }^{13} \mathrm{C}$ NMR spectrum of compound $10\left(100 \mathrm{MHz}, \mathrm{CDCl}_{3}\right)$. 


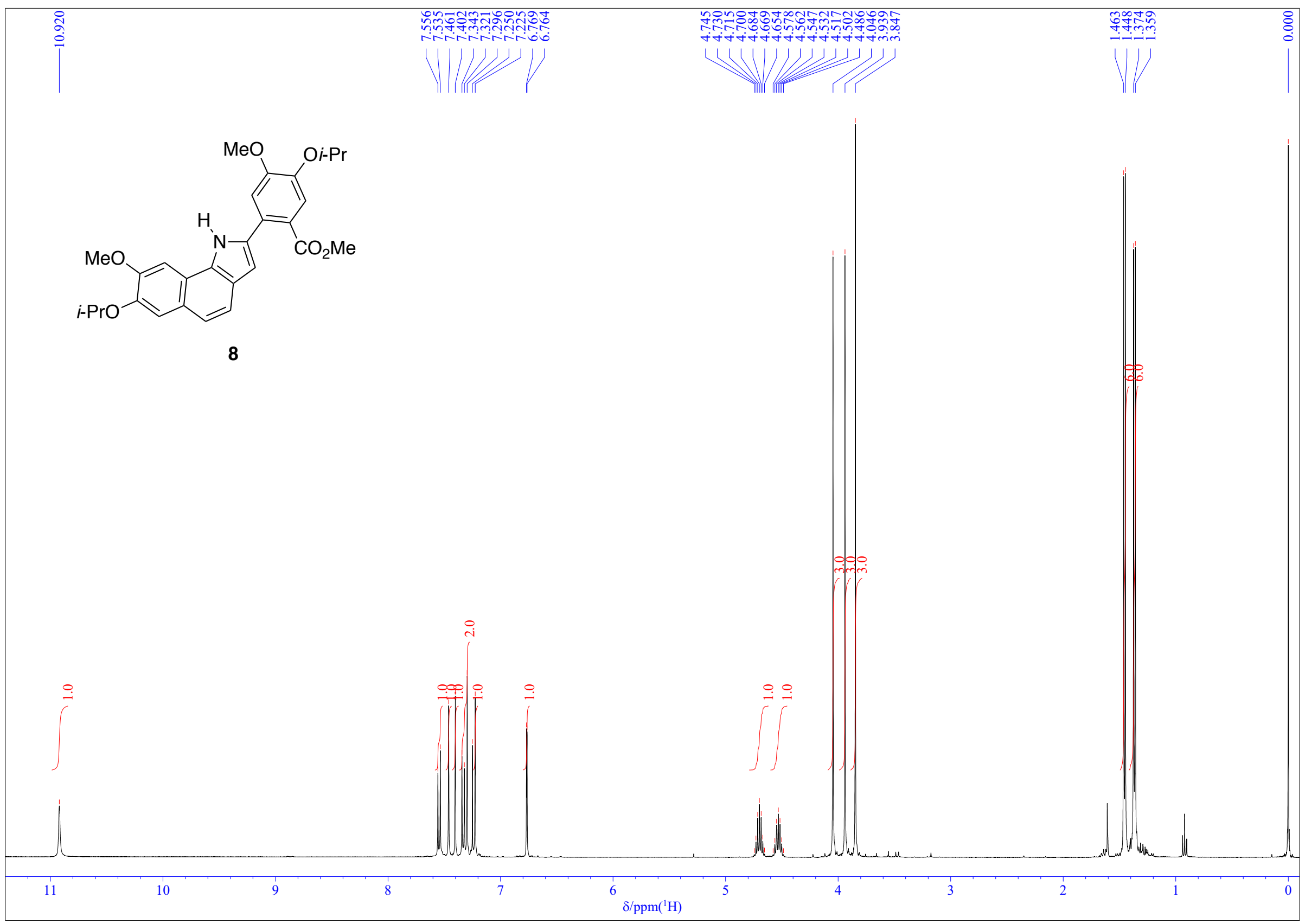

Figure S15. ${ }^{1} \mathrm{H}$ NMR spectrum of compound $8\left(400 \mathrm{MHz}, \mathrm{CDCl}_{3}\right)$. 


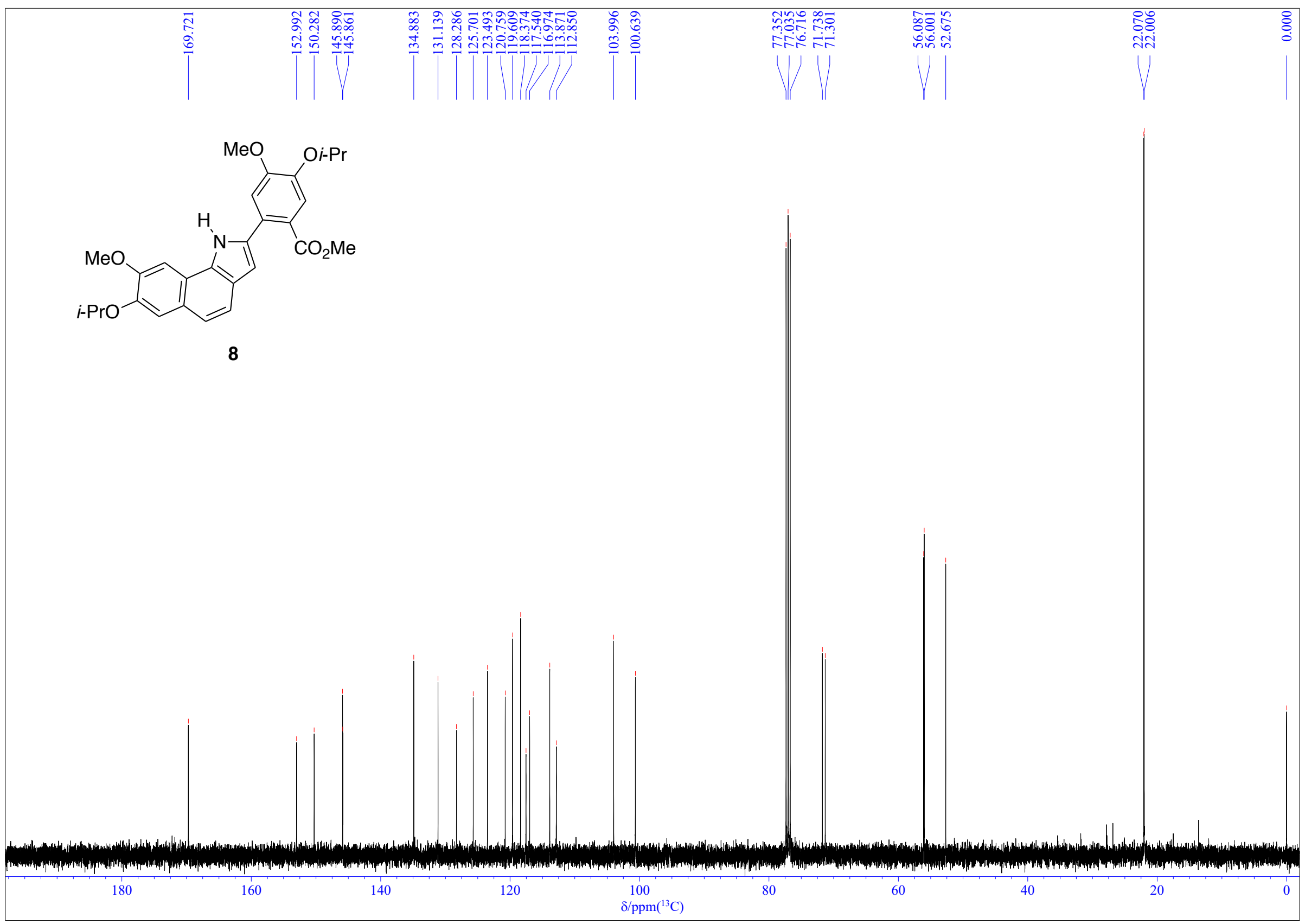

Figure S16. ${ }^{13} \mathrm{C}$ NMR spectrum of compound $8\left(100 \mathrm{MHz}, \mathrm{CDCl}_{3}\right)$. 


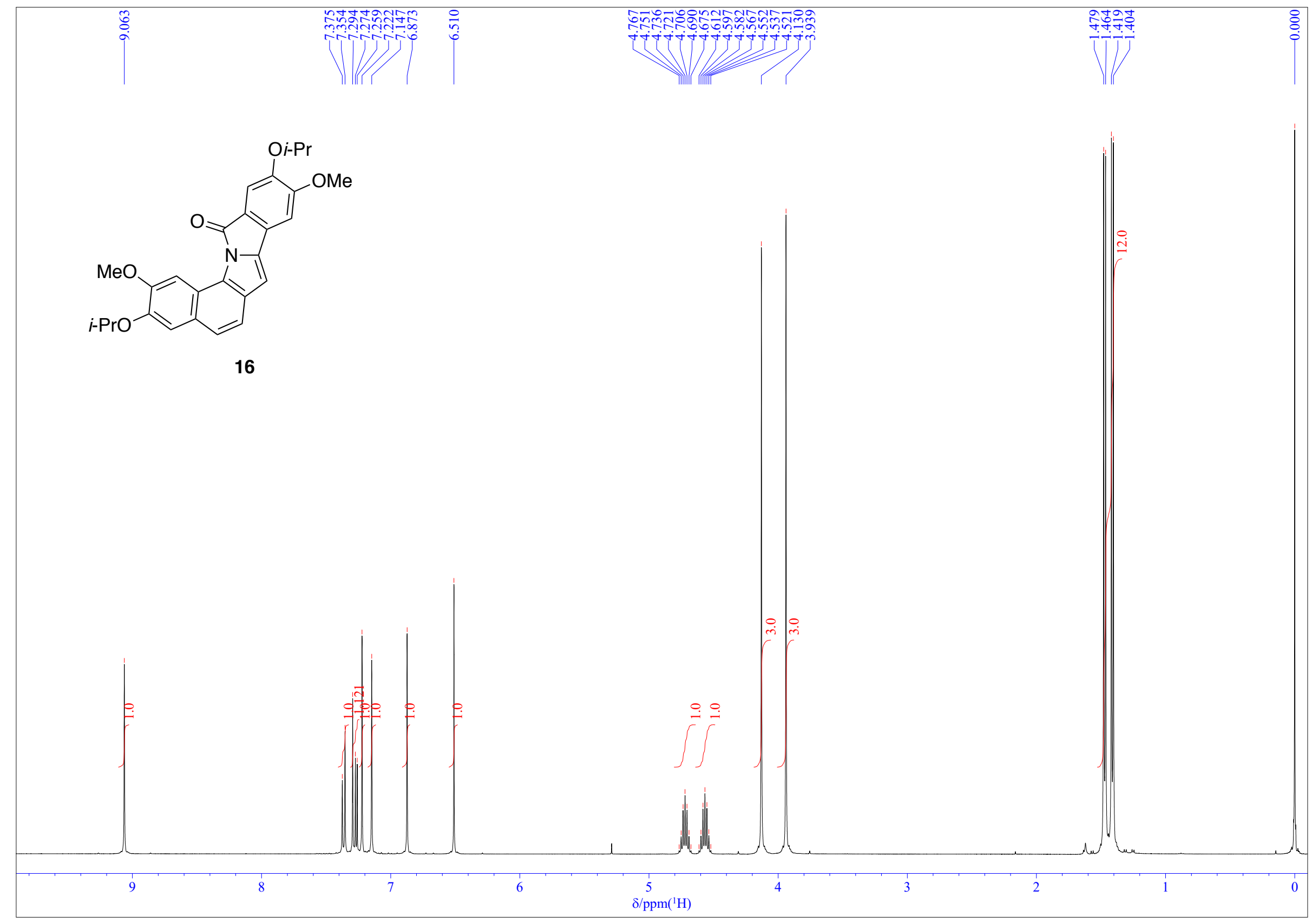

Figure S17. ${ }^{1} \mathrm{H}$ NMR spectrum of compound $16\left(400 \mathrm{MHz}, \mathrm{CDCl}_{3}\right)$. 


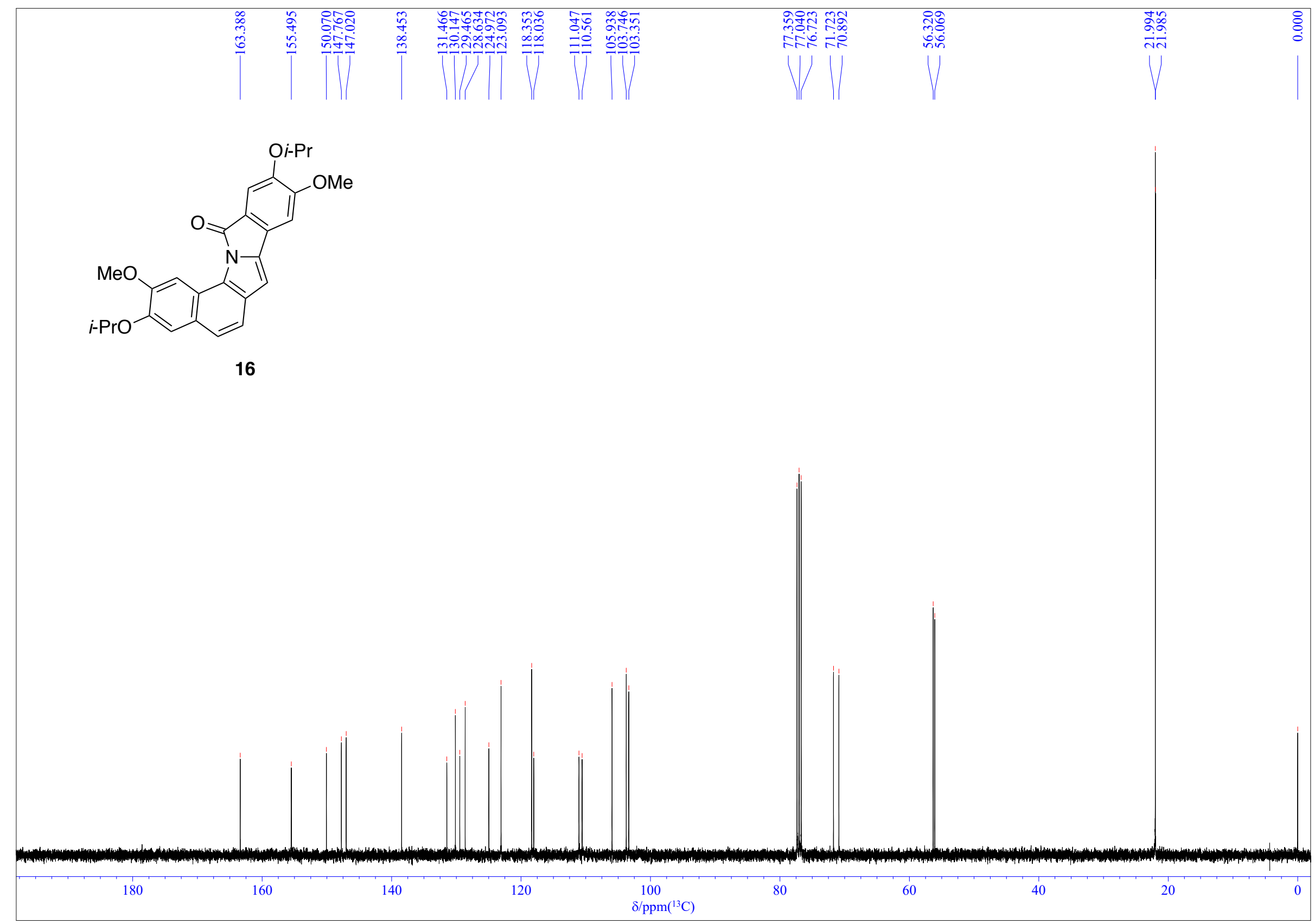

Figure S18. ${ }^{13} \mathrm{C}$ NMR spectrum of compound $16\left(100 \mathrm{MHz}, \mathrm{CDCl}_{3}\right)$. 


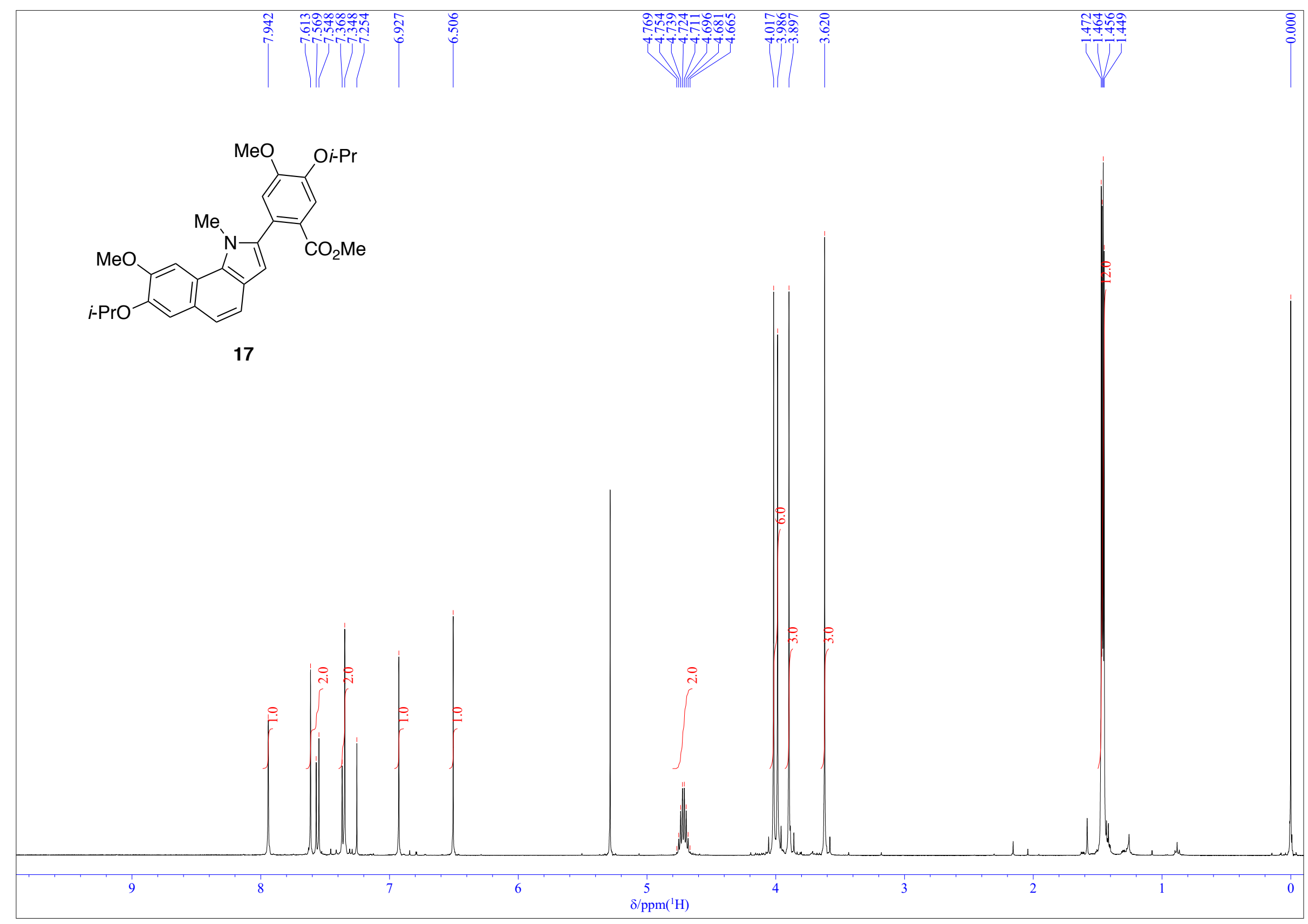

Figure S19. ${ }^{1} \mathrm{H}$ NMR spectrum of compound $17\left(400 \mathrm{MHz}, \mathrm{CDCl}_{3}\right)$. 


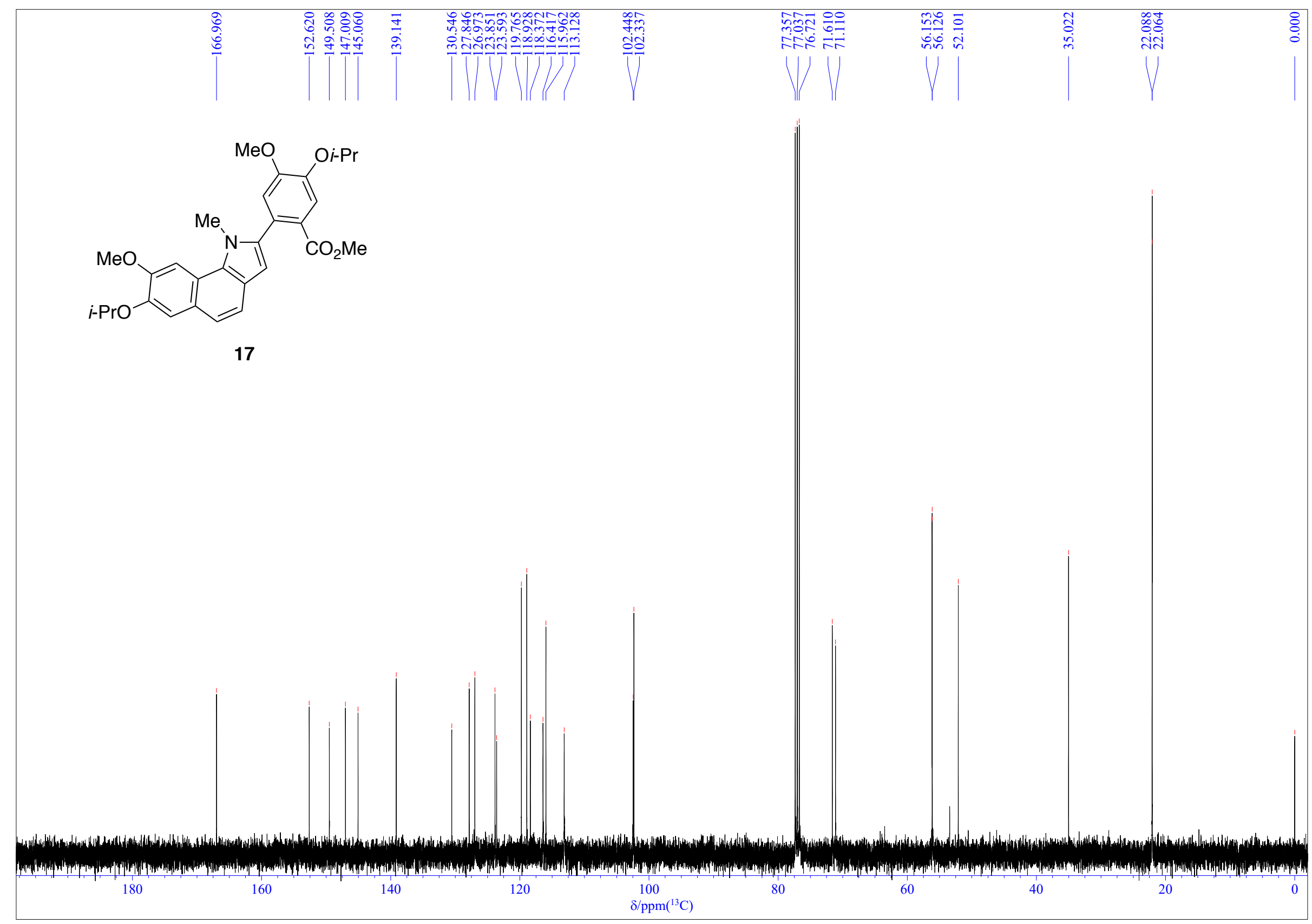

Figure S20. ${ }^{13} \mathrm{C}$ NMR spectrum of compound $17\left(100 \mathrm{MHz}, \mathrm{CDCl}_{3}\right)$. 


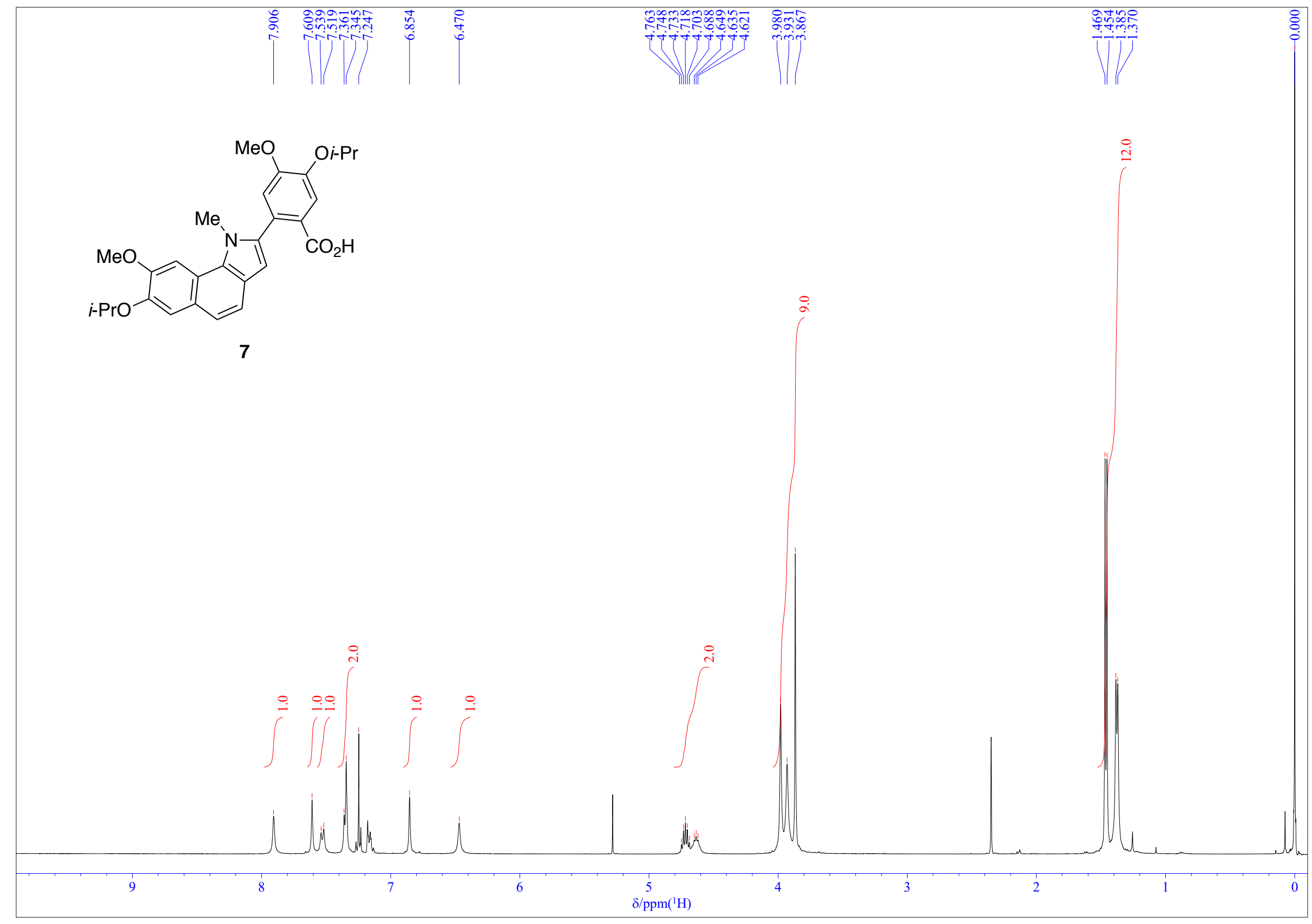

Figure S21. ${ }^{1} \mathrm{H}$ NMR spectrum of compound 7 (400 MHz, $\left.\mathrm{CDCl}_{3}\right)$. 


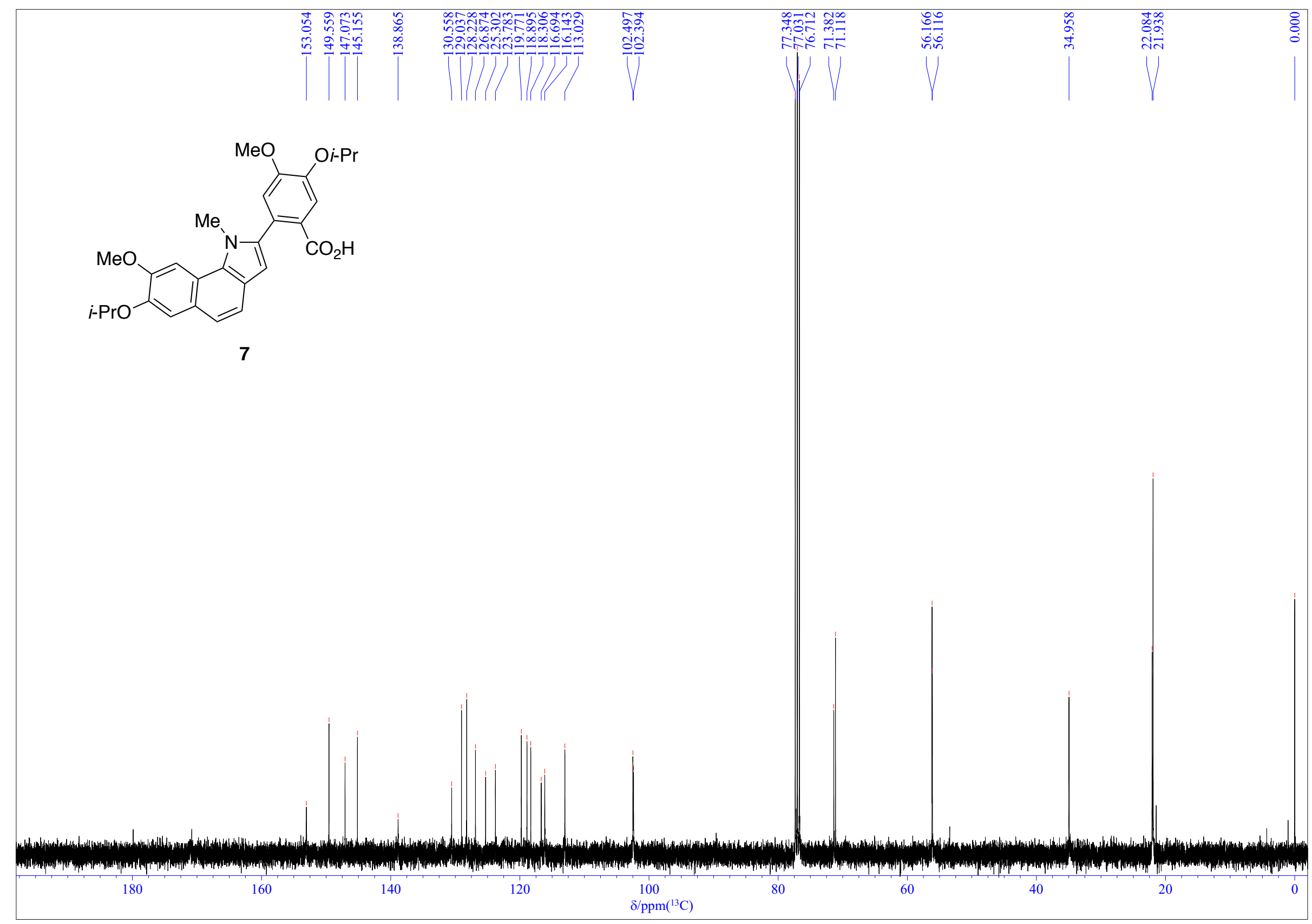

Figure S22. ${ }^{13} \mathrm{C}$ NMR spectrum of compound $7\left(100 \mathrm{MHz}, \mathrm{CDCl}_{3}\right)$. 


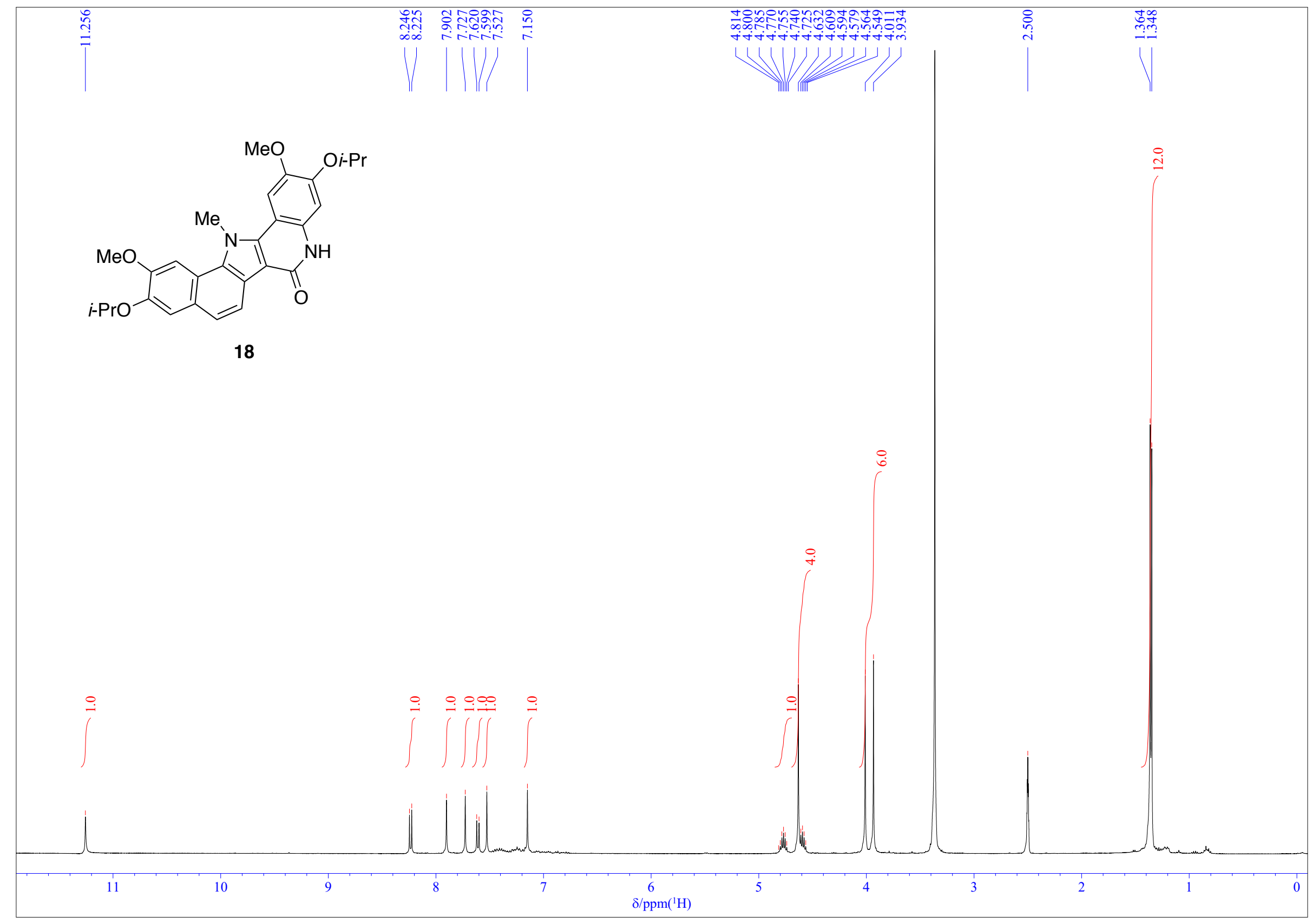

Figure S23. ${ }^{1} \mathrm{H}$ NMR spectrum of compound 18 (400 MHz, DMSO- $\left.d_{6}\right)$. 


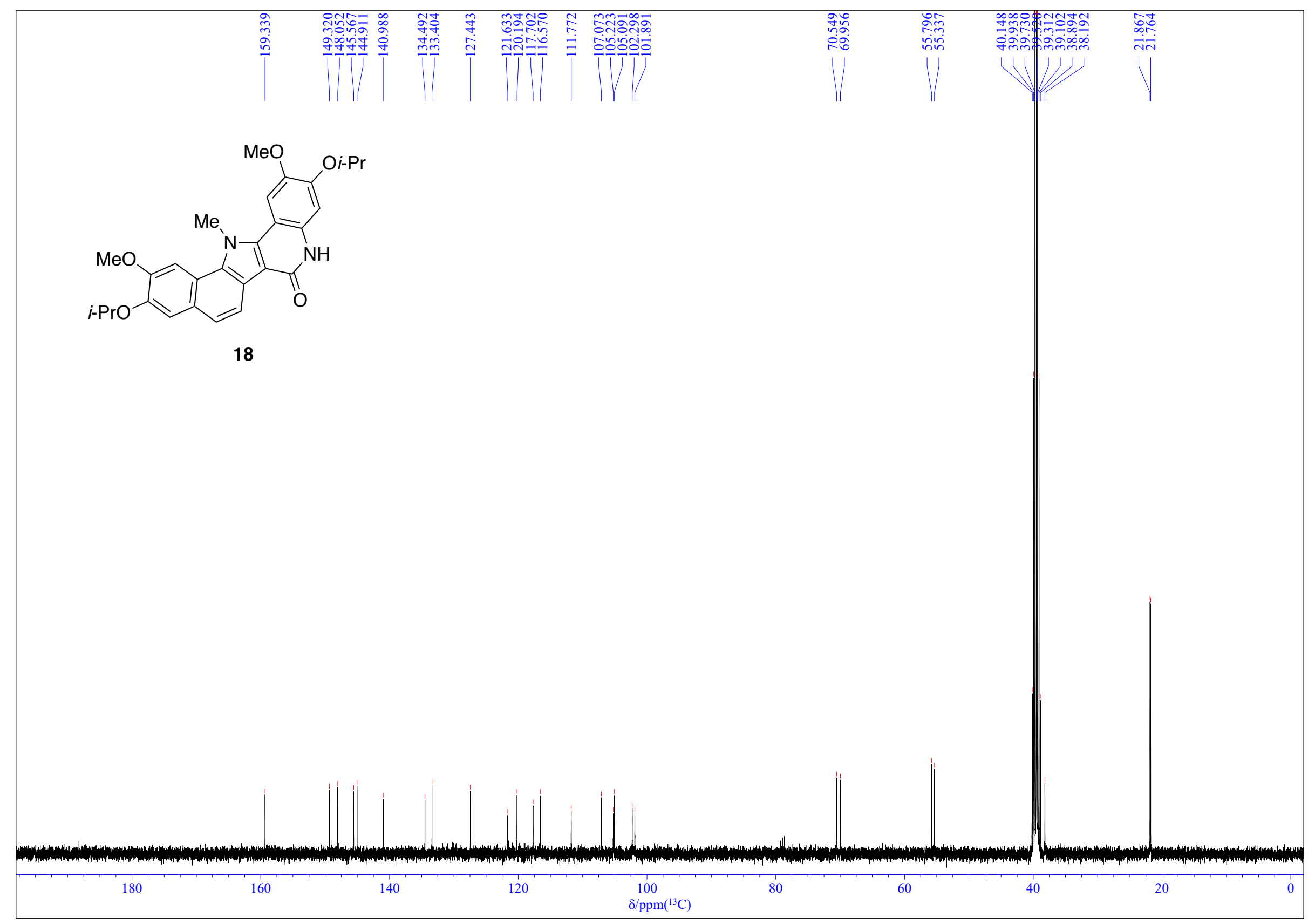

Figure S24. ${ }^{13} \mathrm{C}$ NMR spectrum of compound $18\left(100 \mathrm{MHz}\right.$, DMSO- $\left.d_{6}\right)$. 


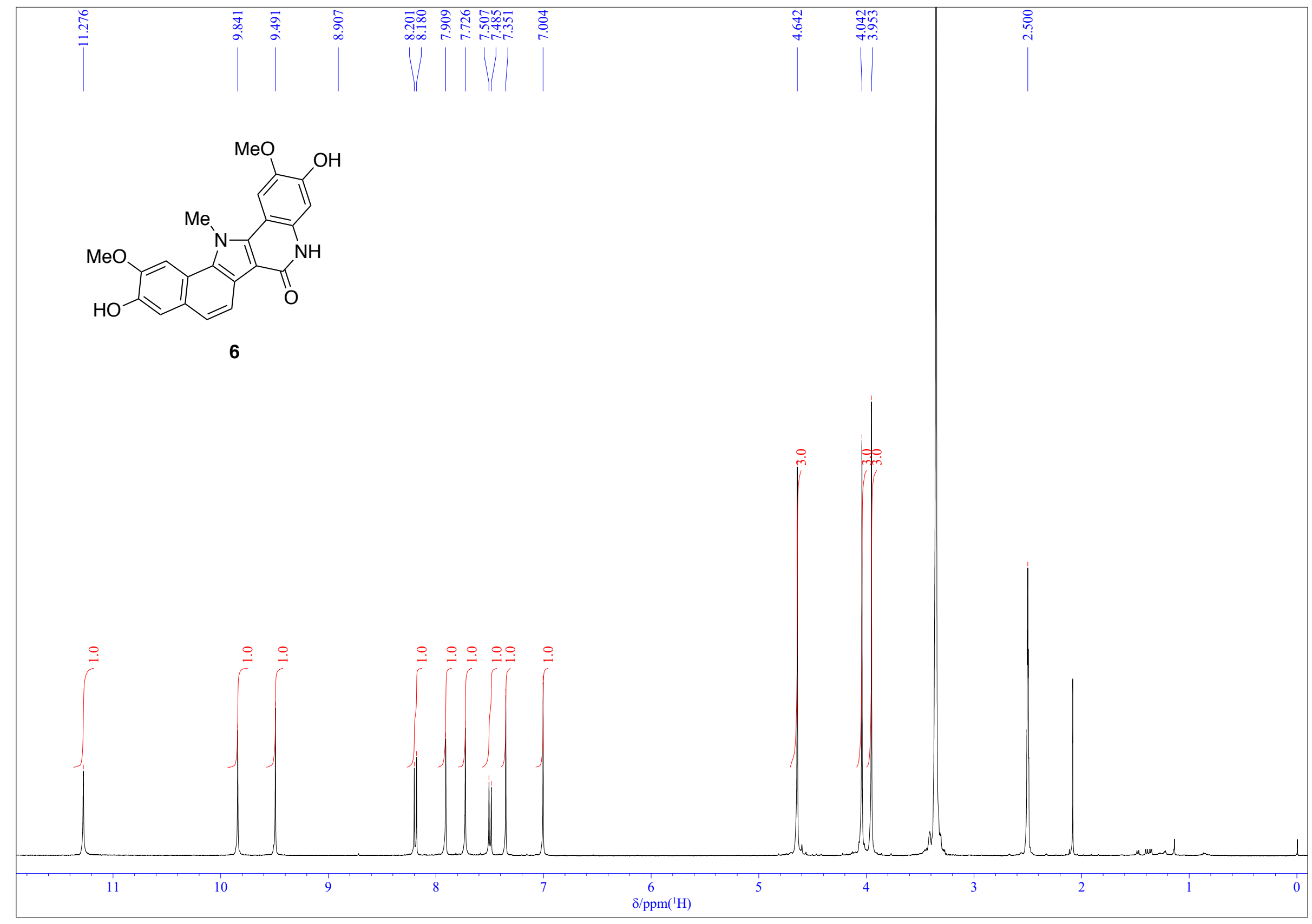

Figure S25. ${ }^{1} \mathrm{H}$ NMR spectrum of compound 6 (400 MHz, DMSO- $d_{6}$ ). 


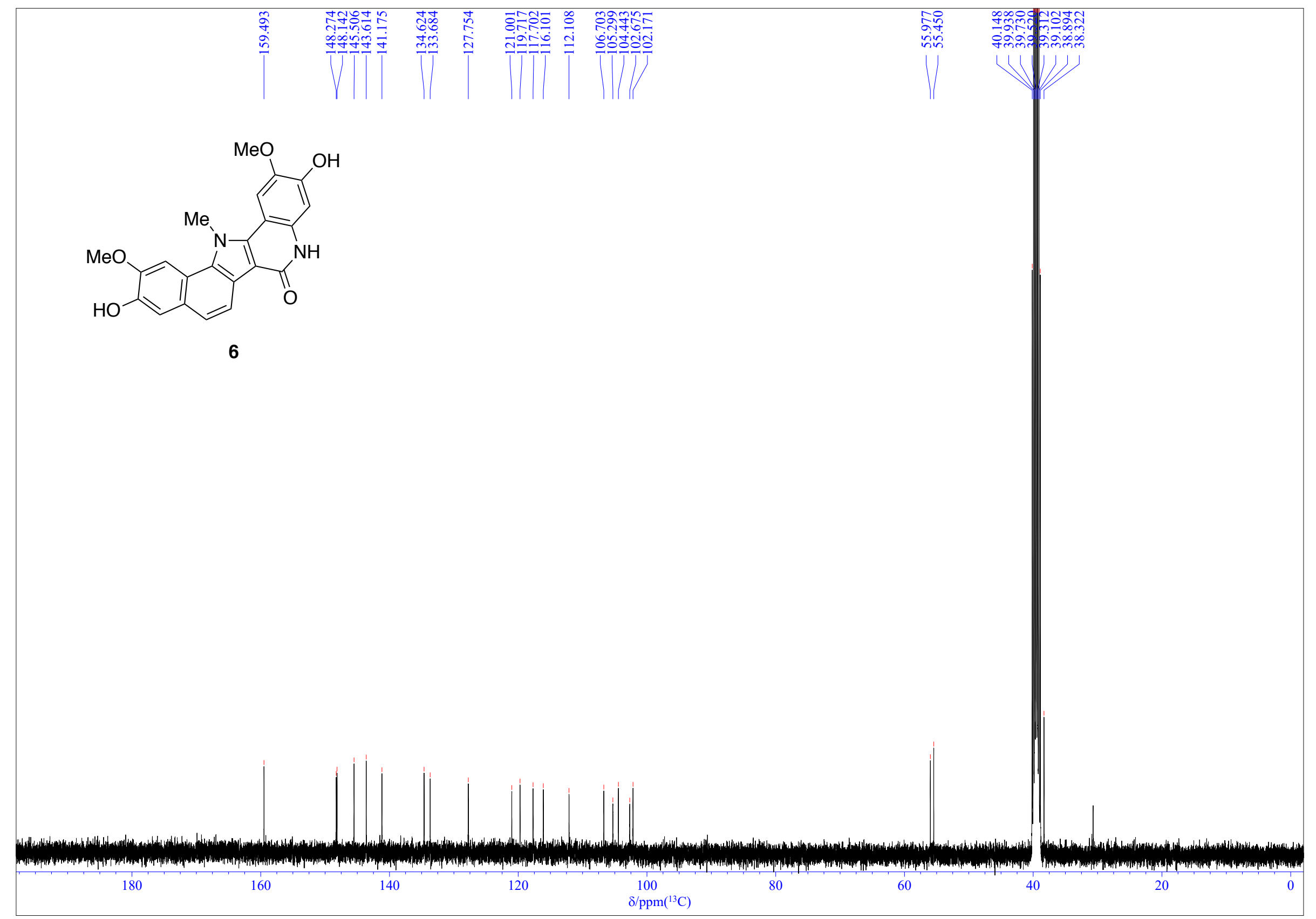

Figure S26. ${ }^{13} \mathrm{C}$ NMR spectrum of compound $6\left(100 \mathrm{MHz}\right.$, DMSO- $\left.d_{6}\right)$. 


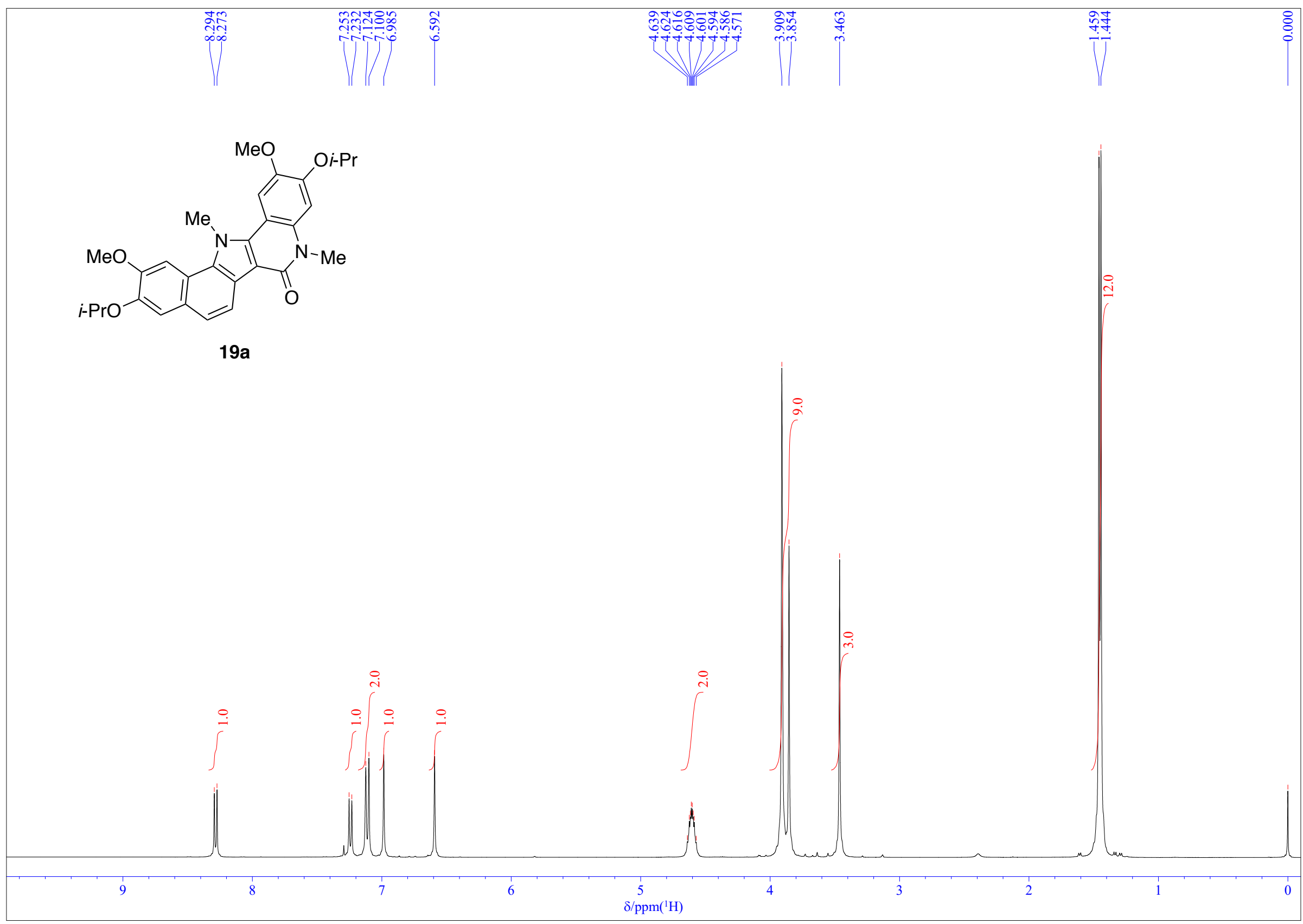

Figure S27. ${ }^{1} \mathrm{H}$ NMR spectrum of compound 19a $\left(400 \mathrm{MHz}, \mathrm{CDCl}_{3}\right)$. 


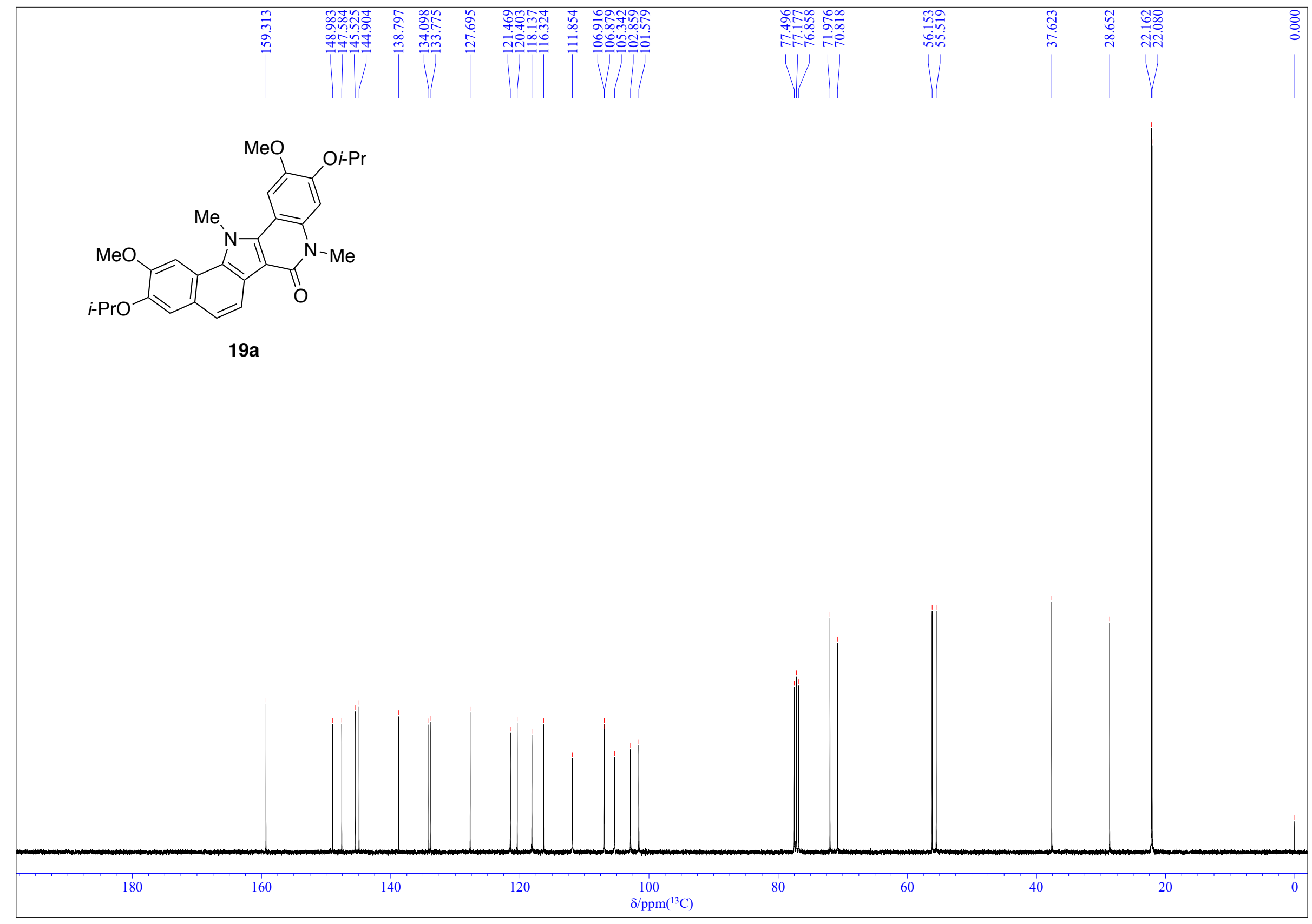

Figure S28. ${ }^{13} \mathrm{C}$ NMR spectrum of compound $19 a\left(100 \mathrm{MHz}, \mathrm{CDCl}_{3}\right)$. 


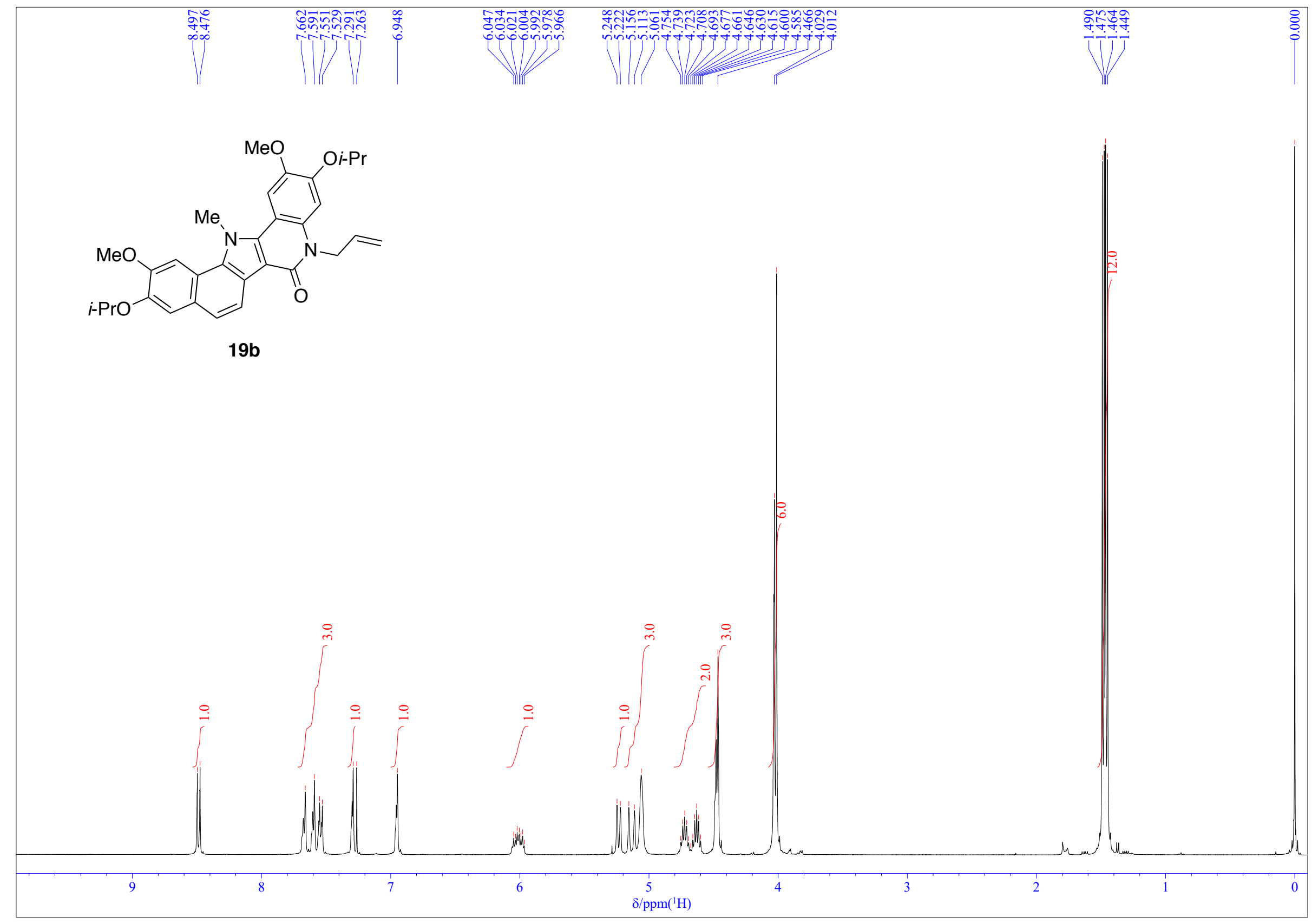

Figure S29. ${ }^{1} \mathrm{H}$ NMR spectrum of compound $19 b\left(400 \mathrm{MHz}, \mathrm{CDCl}_{3}\right)$. 


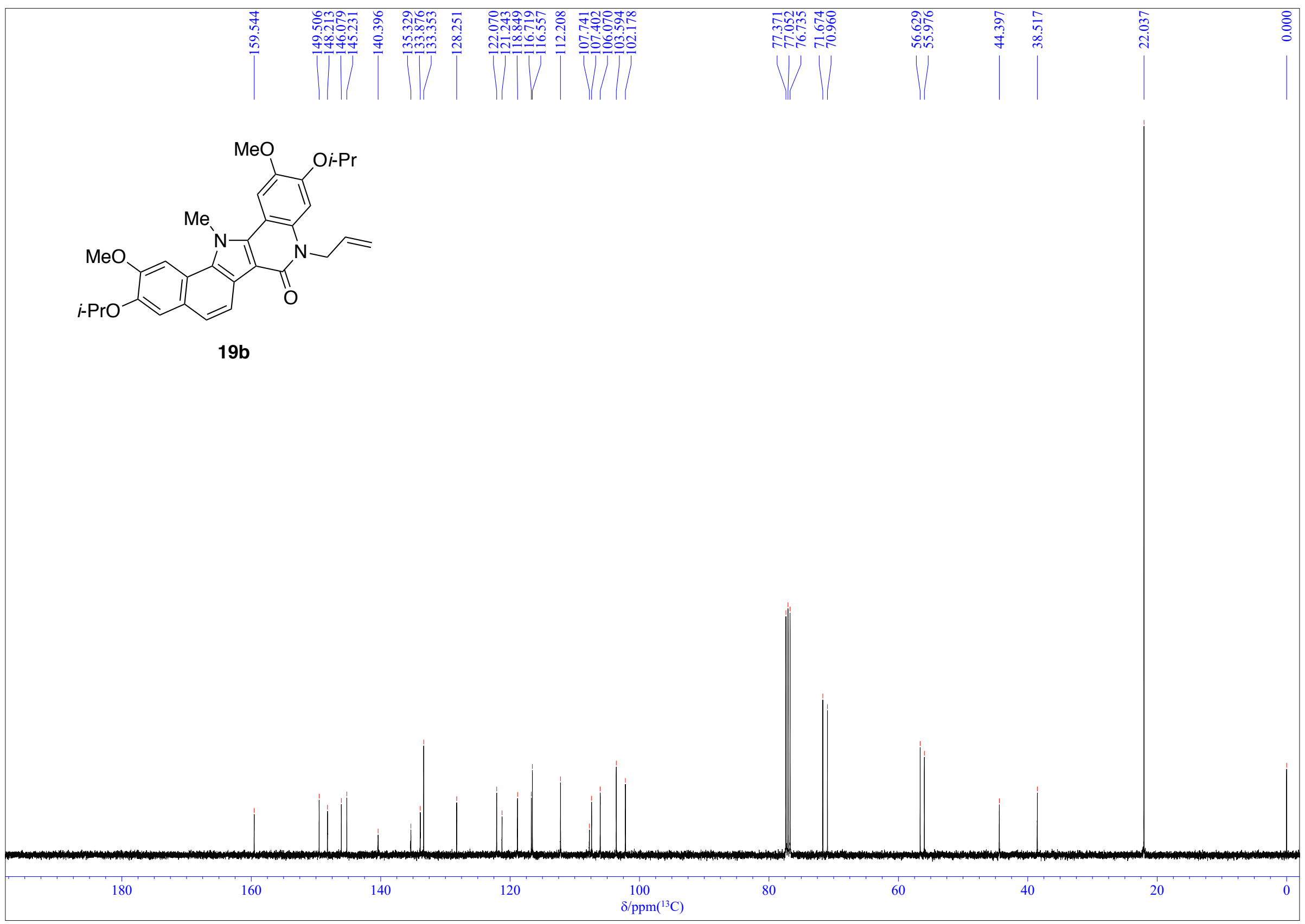

Figure S30. ${ }^{13} \mathrm{C}$ NMR spectrum of compound $19 b\left(100 \mathrm{MHz}, \mathrm{CDCl}_{3}\right)$. 


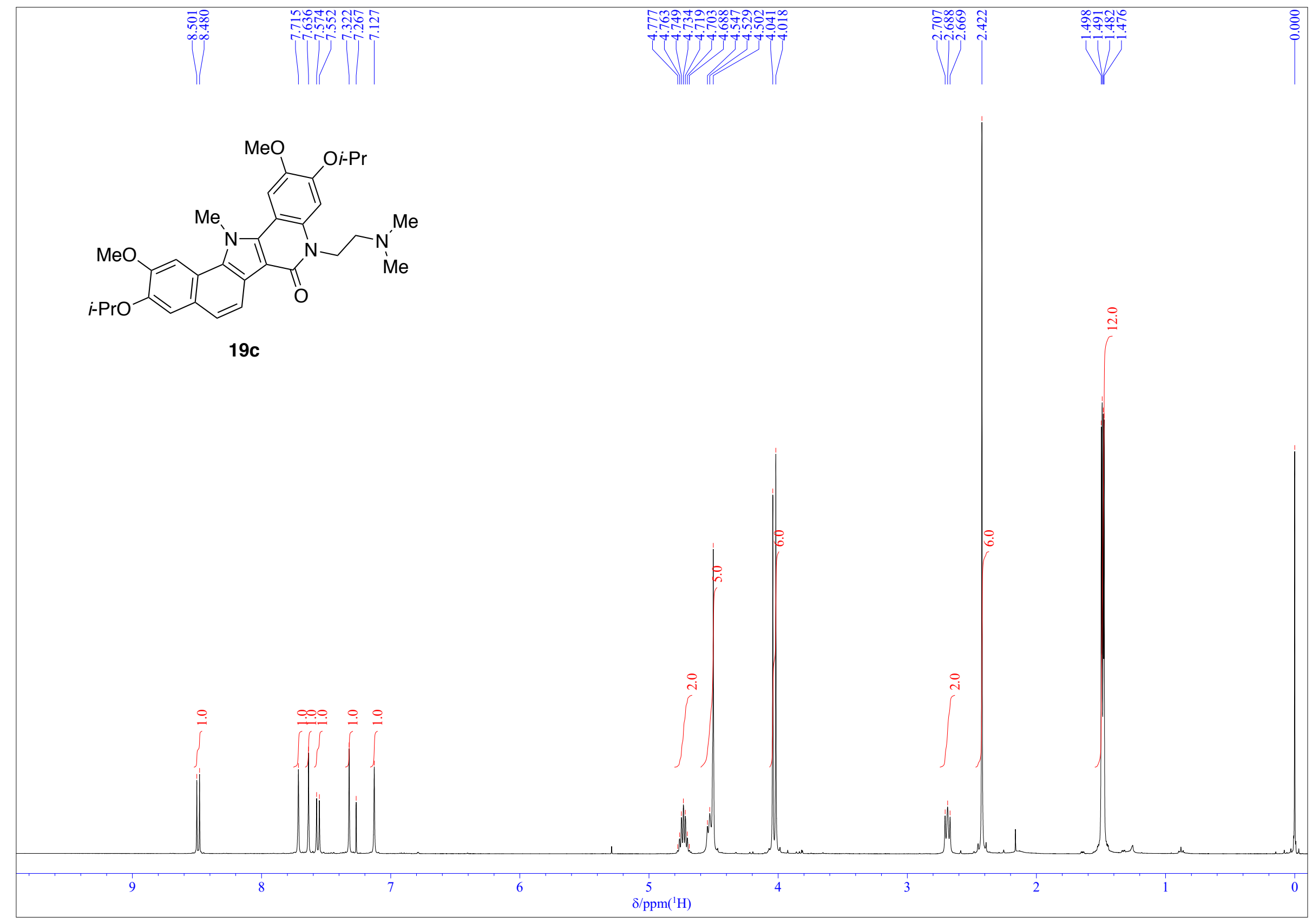

Figure S31. ${ }^{1} \mathrm{H}$ NMR spectrum of compound $19 \mathrm{c}\left(400 \mathrm{MHz}, \mathrm{CDCl}_{3}\right)$. 


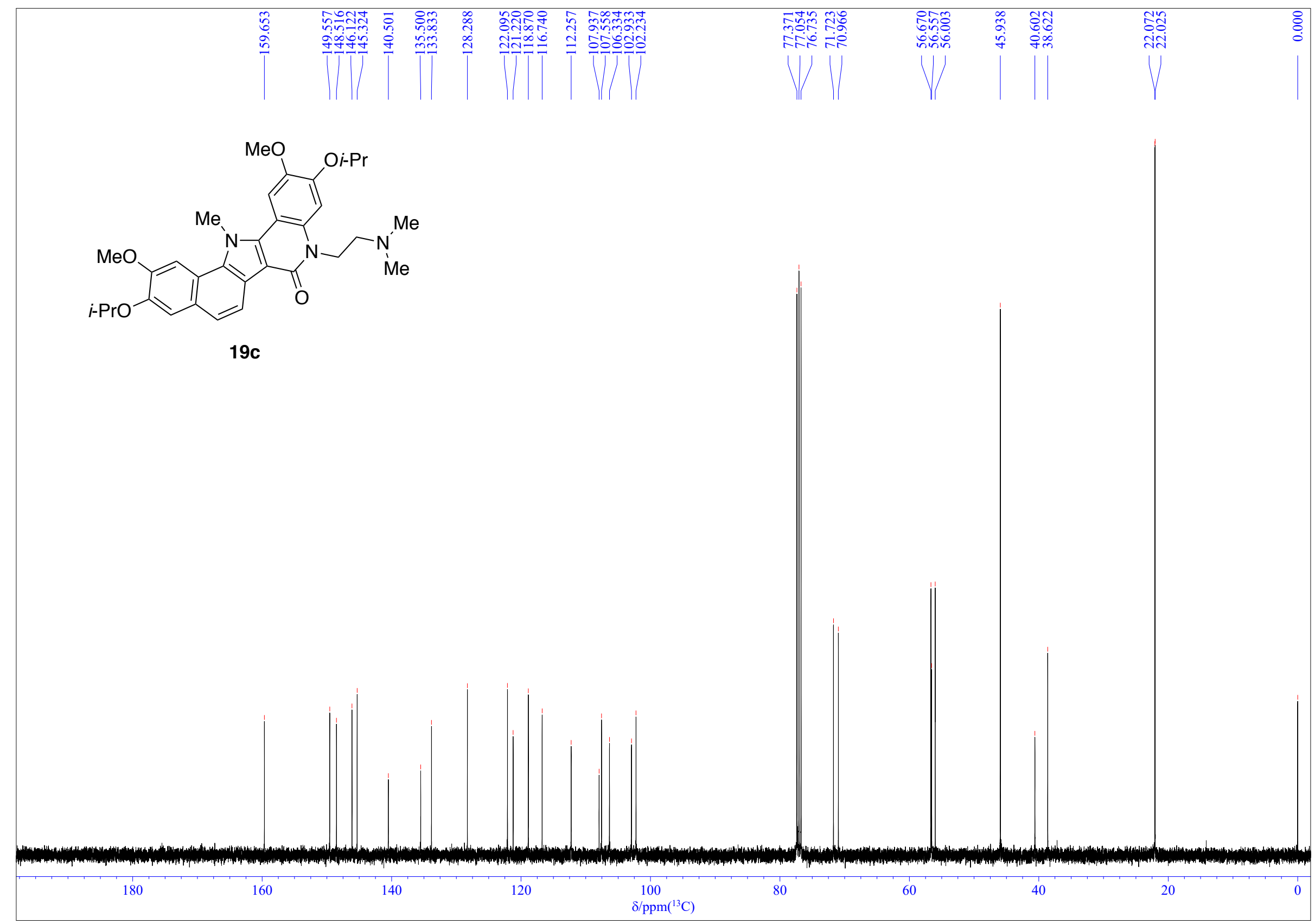

Figure S32. ${ }^{13} \mathrm{C}$ NMR spectrum of compound $19 \mathrm{c}\left(100 \mathrm{MHz}, \mathrm{CDCl}_{3}\right)$. 


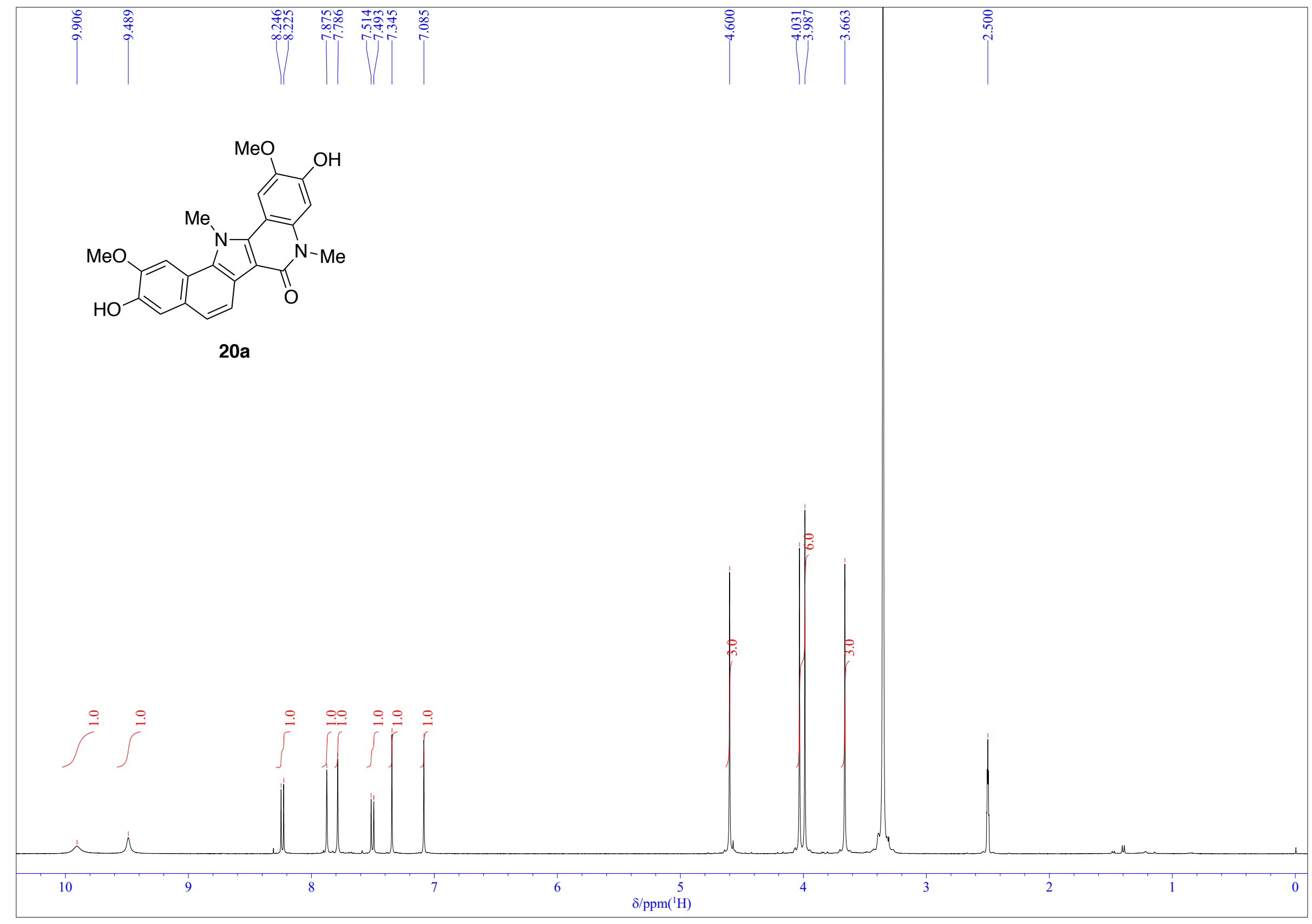

Figure S33. ${ }^{1} \mathrm{H}$ NMR spectrum of compound 20a (400 MHz, DMSO- $\left.d_{6}\right)$. 


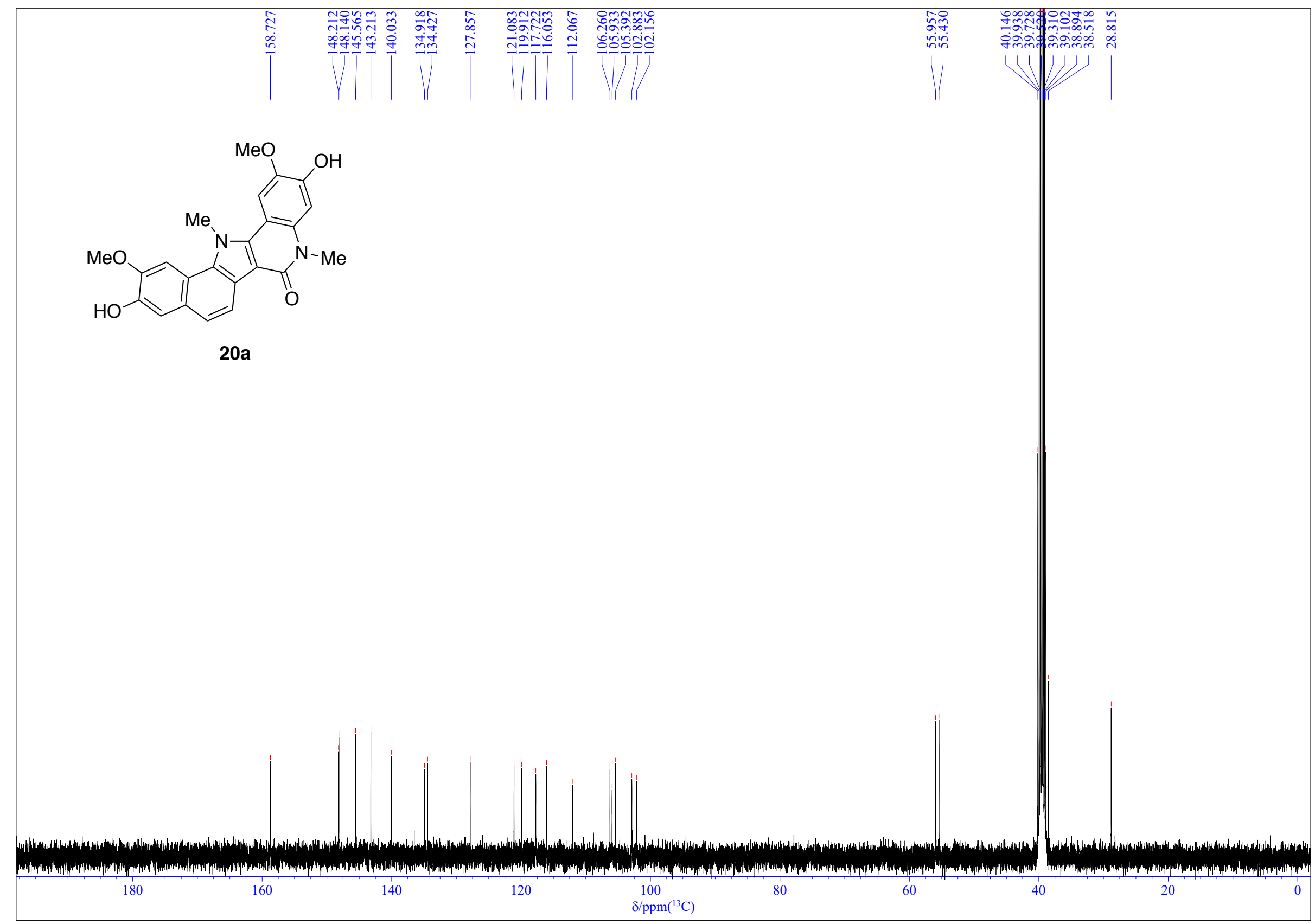

Figure S34. ${ }^{13} \mathrm{C}$ NMR spectrum of compound 20a (100 MHz, DMSO- $\left.d_{6}\right)$. 


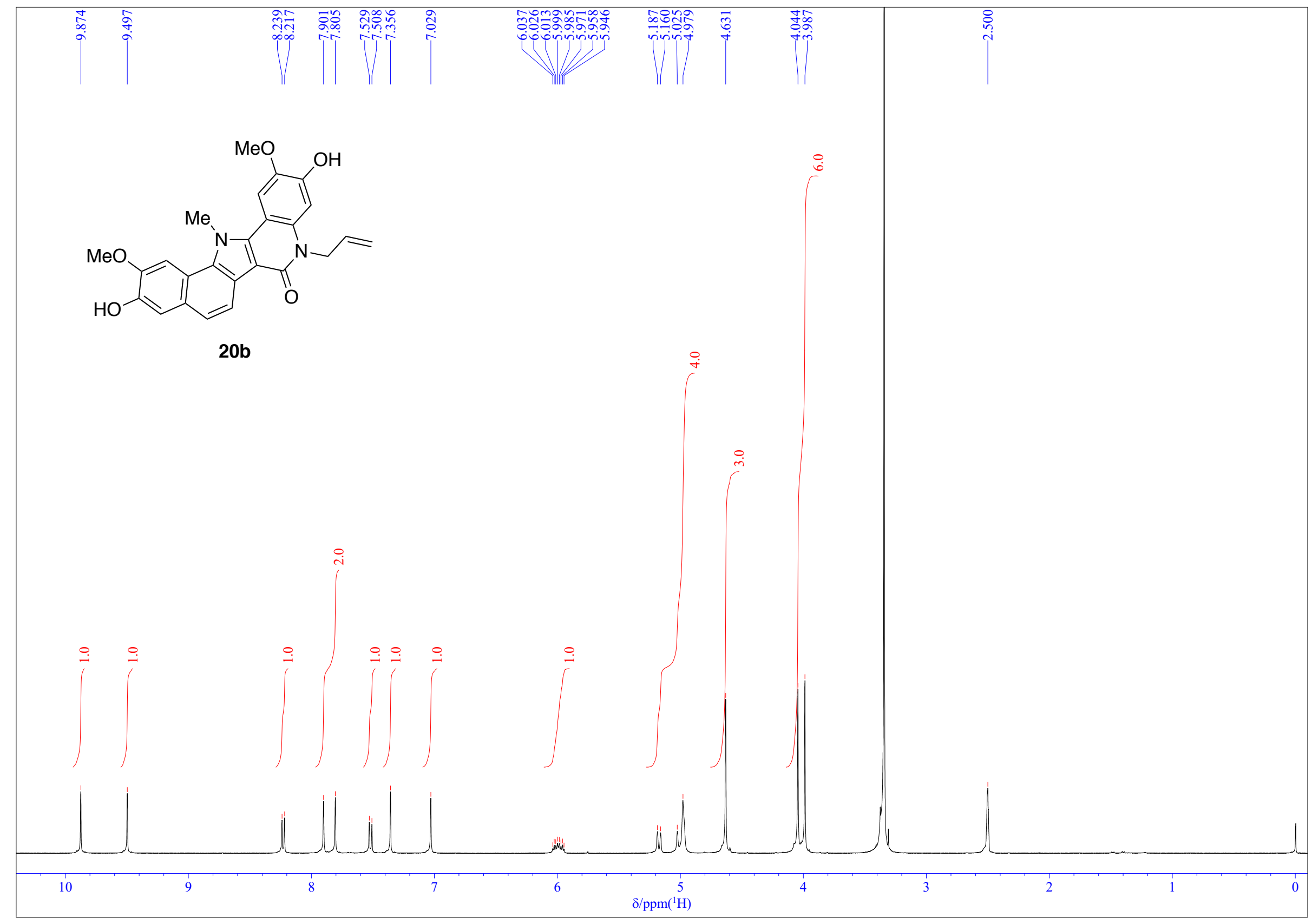

Figure S35. ${ }^{1} \mathrm{H}$ NMR spectrum of compound 20b (400 MHz, DMSO- $d_{6}$ ). 


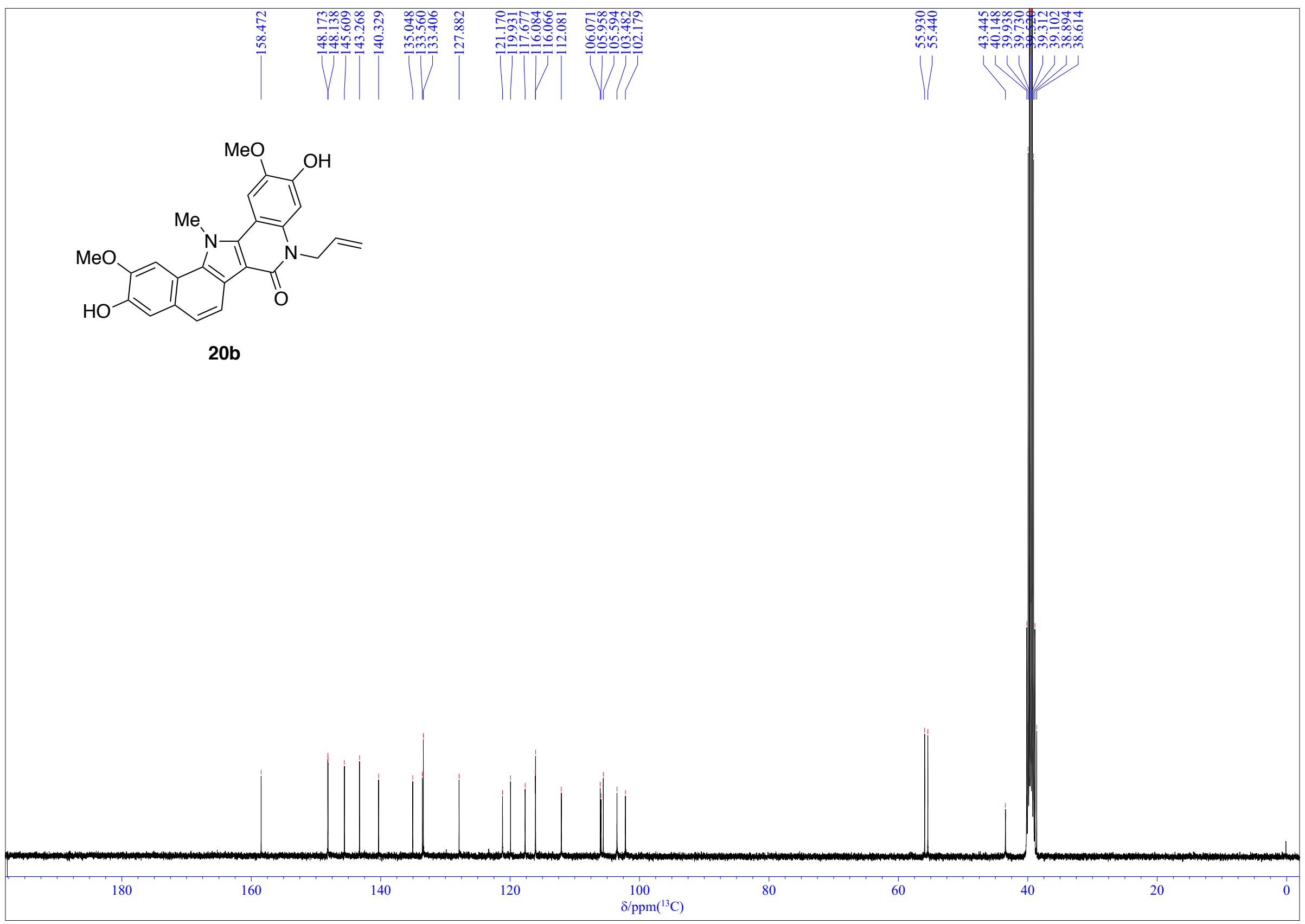

Figure S36. ${ }^{13} \mathrm{C}$ NMR spectrum of compound $20 \mathbf{b}$ (100 MHz, DMSO- $d_{6}$ ). 


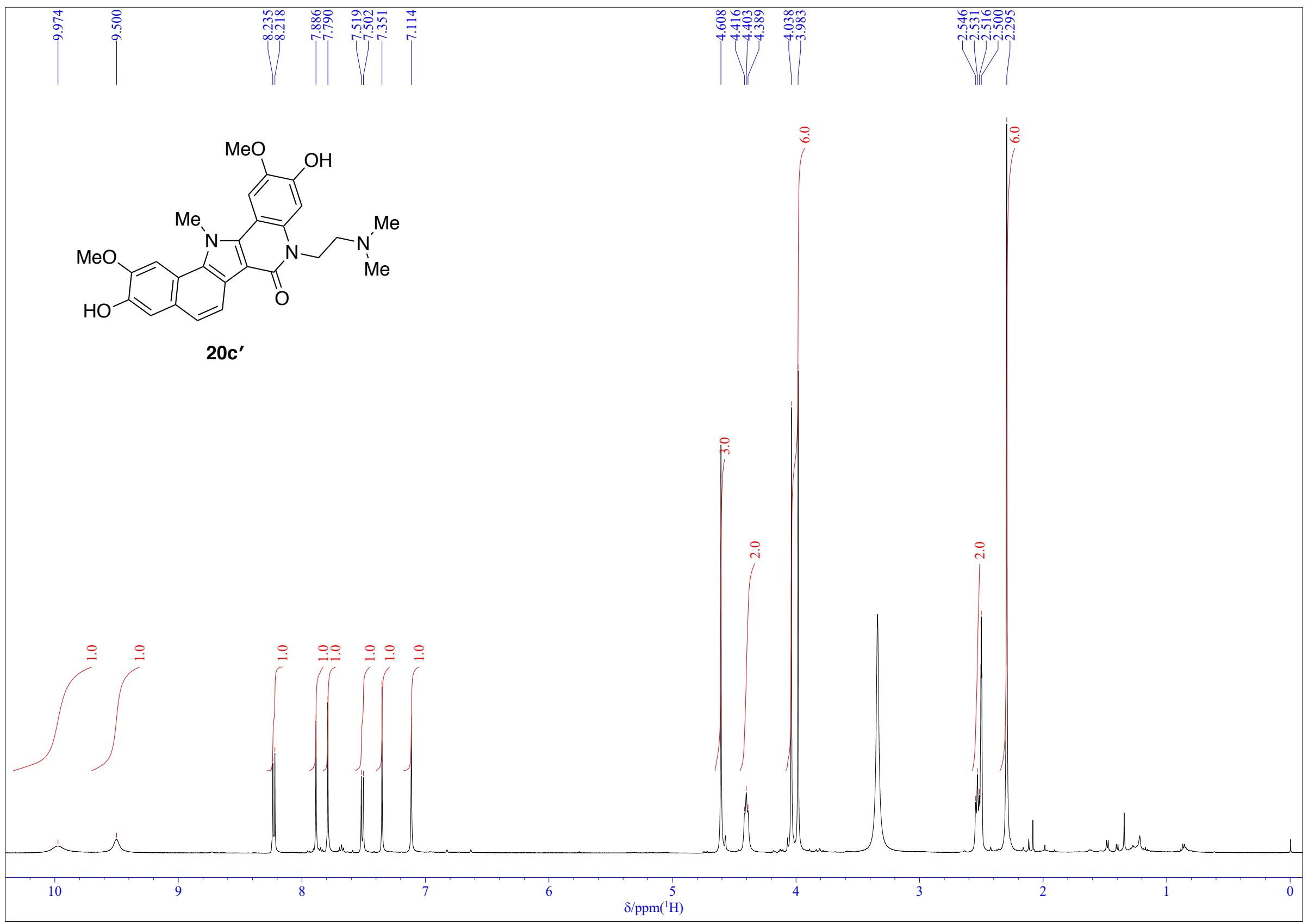

Figure S37. ${ }^{1} \mathrm{H}$ NMR spectrum of compound 20c' (500 MHz, DMSO- $\left.d_{6}\right)$. 


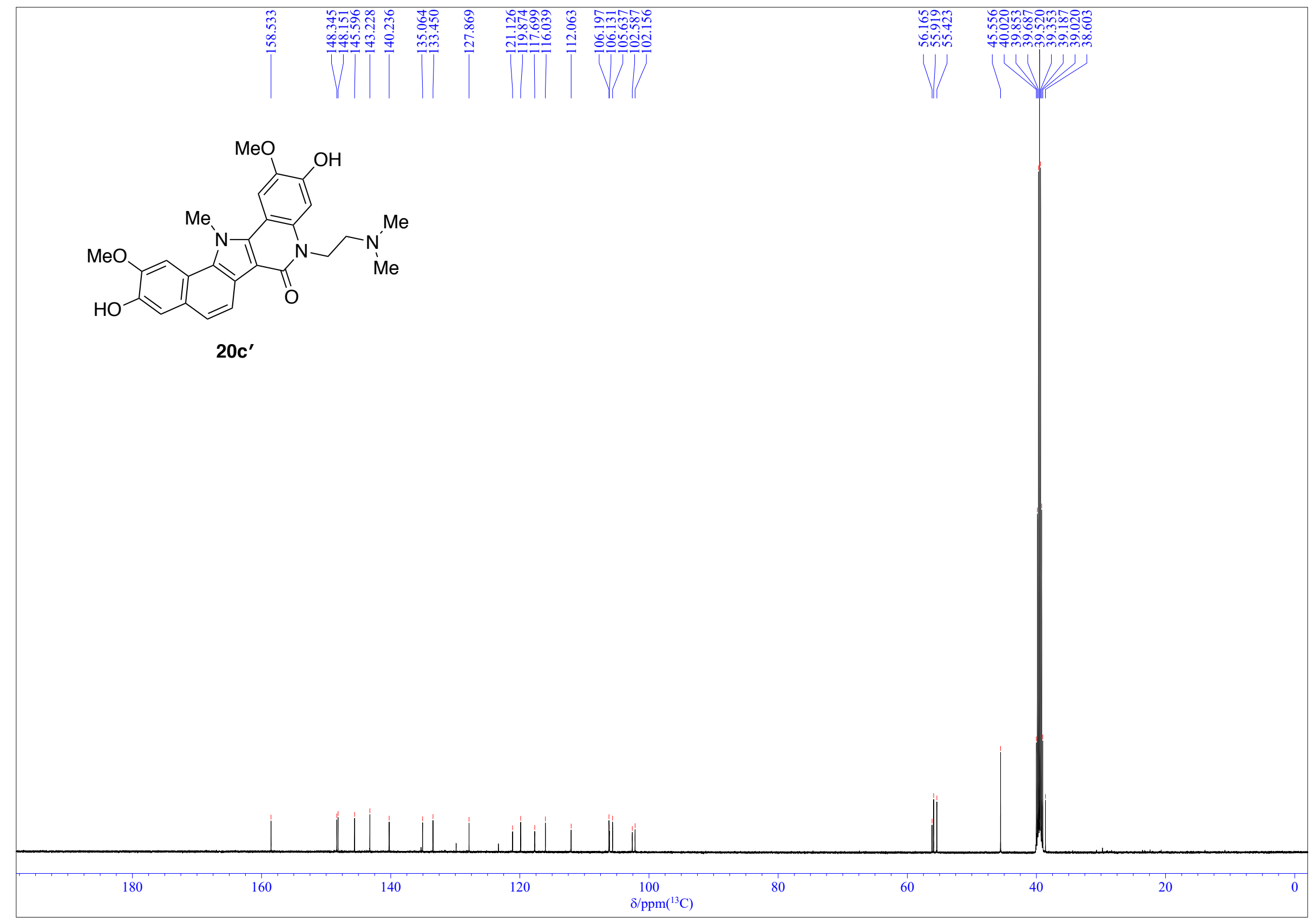

Figure S38. ${ }^{13} \mathrm{C}$ NMR spectrum of compound 20c' (126 MHz, DMSO- $d_{6}$ ). 


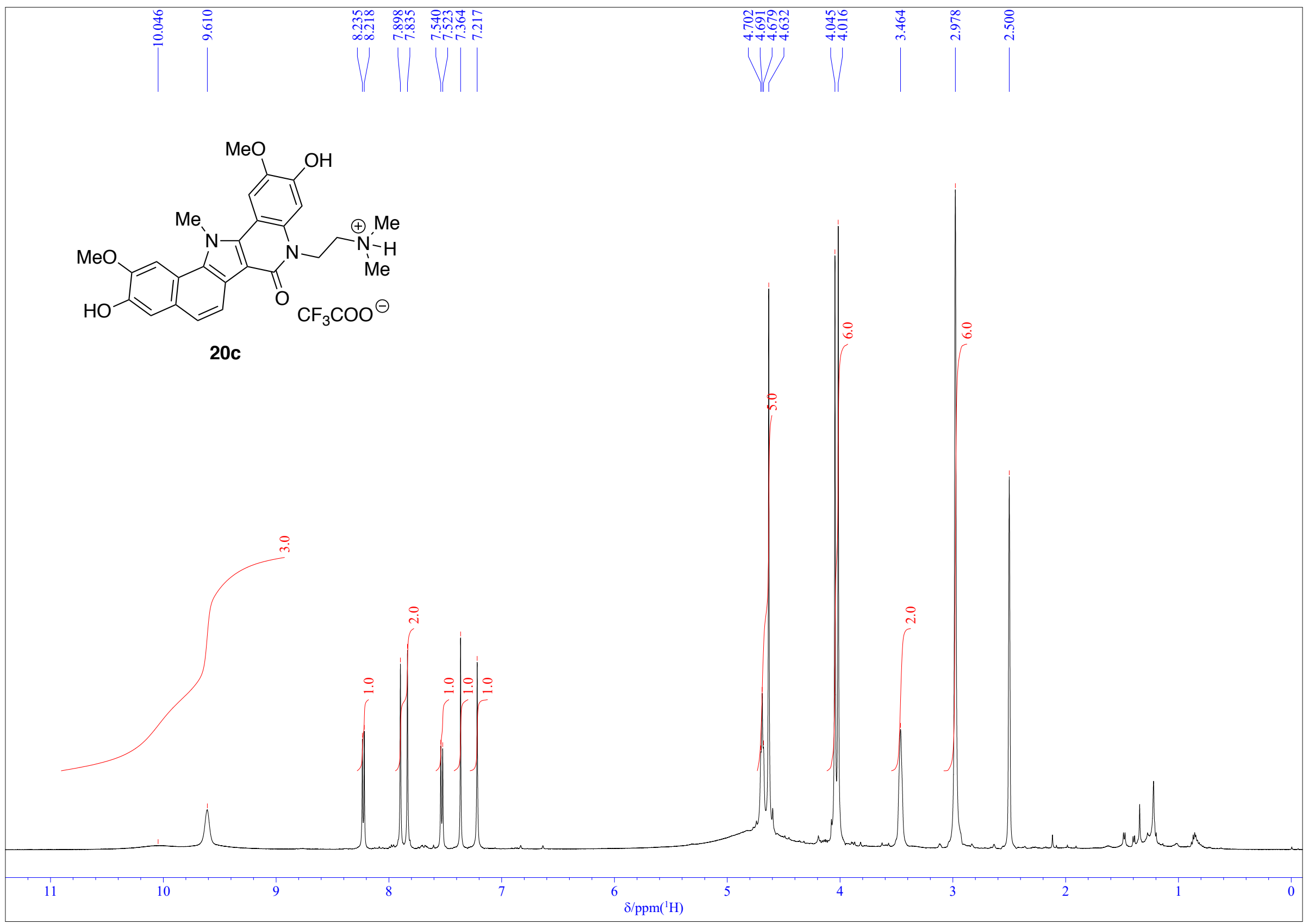

Figure S39. ${ }^{1} \mathrm{H}$ NMR spectrum of compound 20c (500 MHz, DMSO- $\left.d_{6}\right)$. 


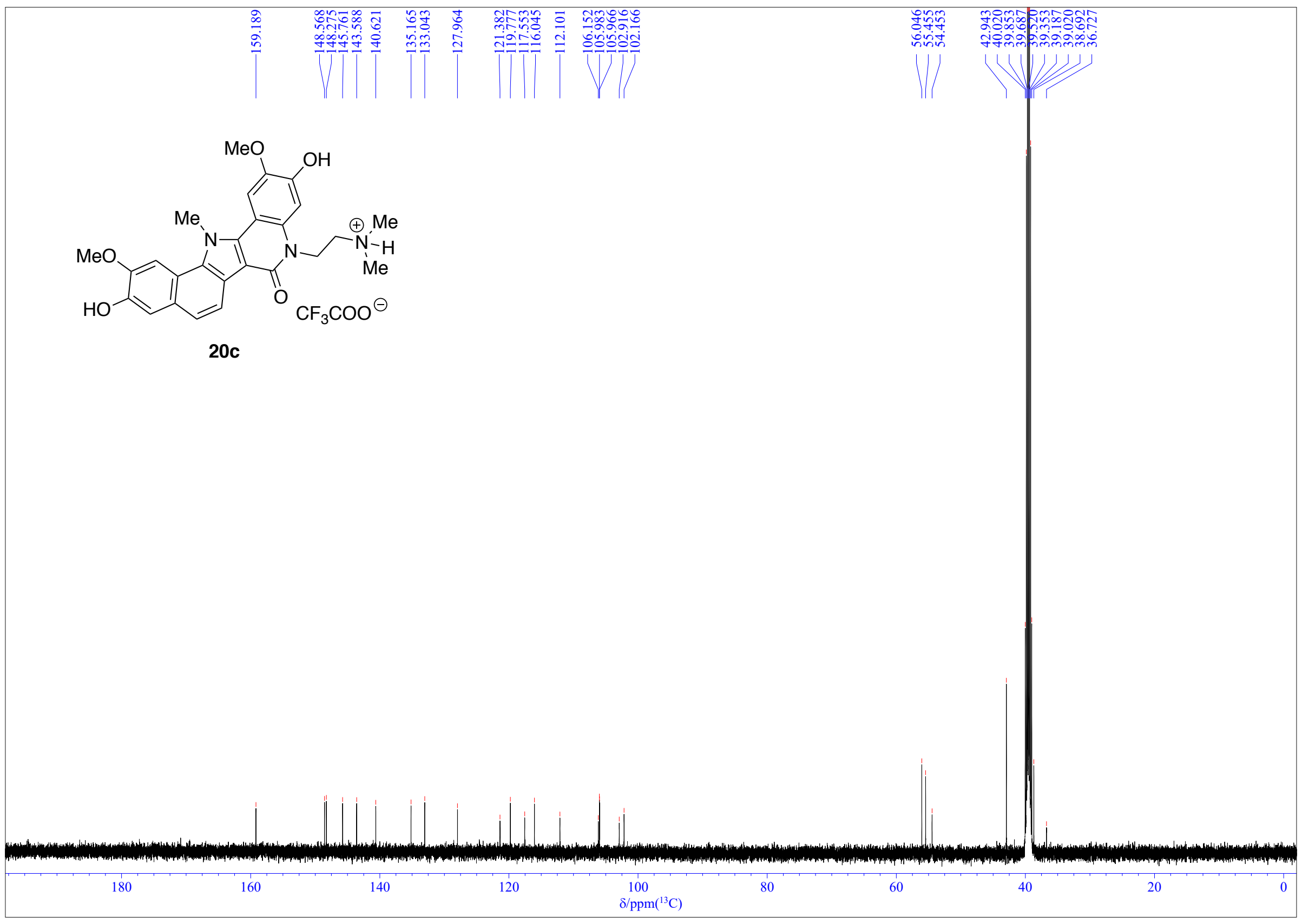

Figure S40. ${ }^{13} \mathrm{C}$ NMR spectrum of compound $20 \mathrm{c}\left(126 \mathrm{MHz}\right.$, DMSO- $\left.d_{6}\right)$. 


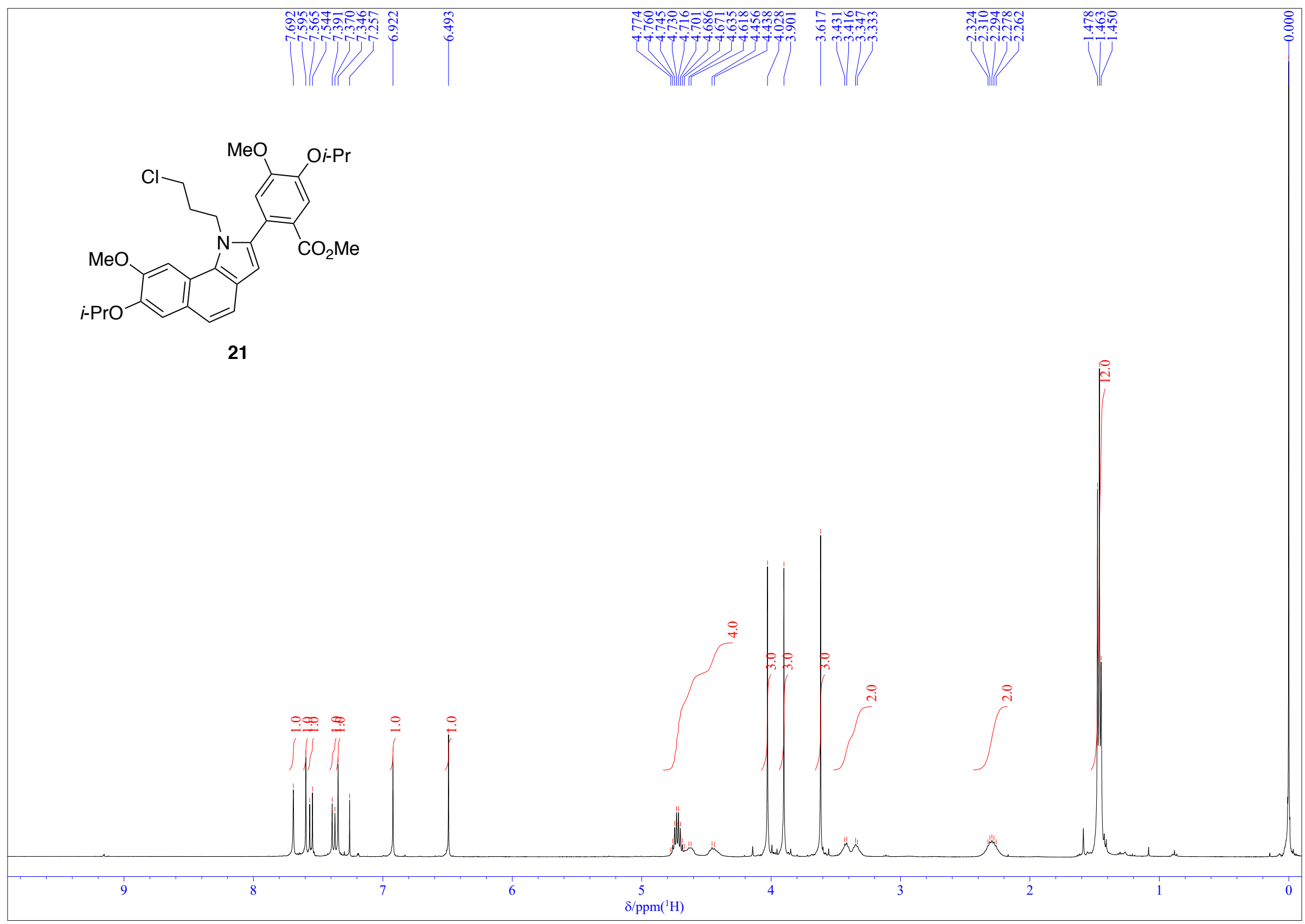

Figure S41. ${ }^{1} \mathrm{H}$ NMR spectrum of compound $21\left(400 \mathrm{MHz}, \mathrm{CDCl}_{3}\right)$. 


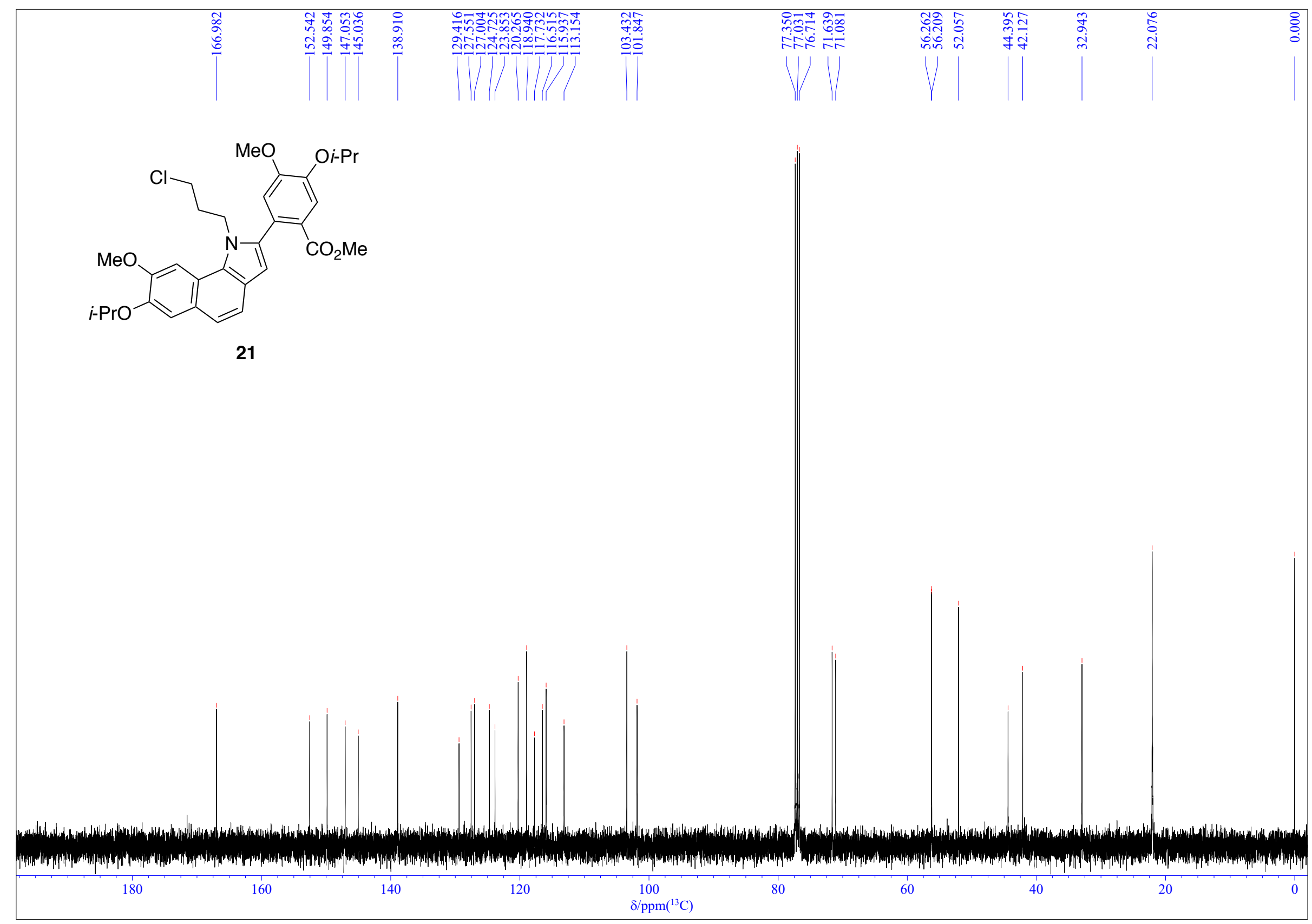

Figure S42. ${ }^{13} \mathrm{C}$ NMR spectrum of compound $21\left(100 \mathrm{MHz}, \mathrm{CDCl}_{3}\right)$. 


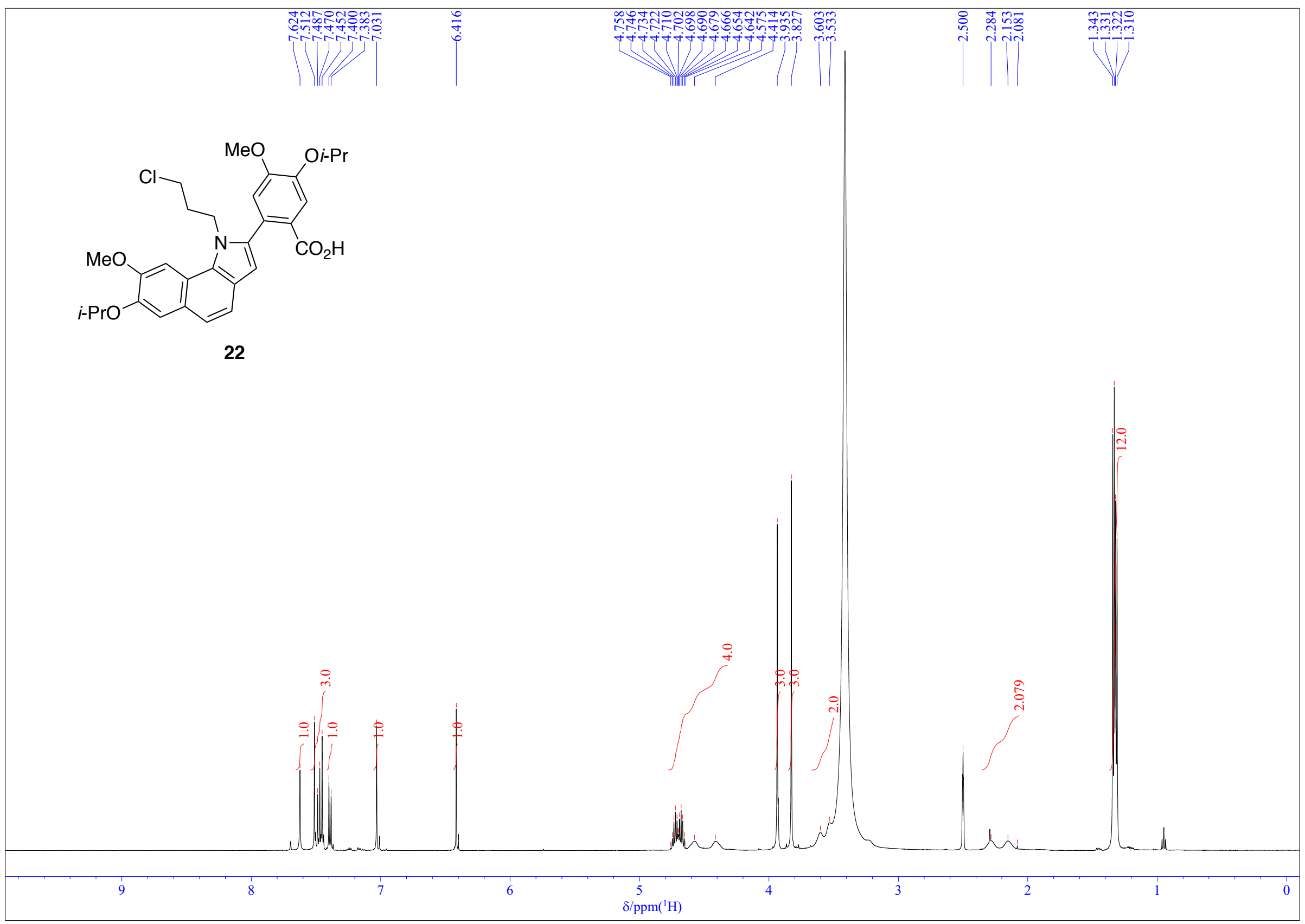

Figure S43. ${ }^{1} \mathrm{H}$ NMR spectrum of compound 22 (500 MHz, DMSO- $\left.d_{6}\right)$. 


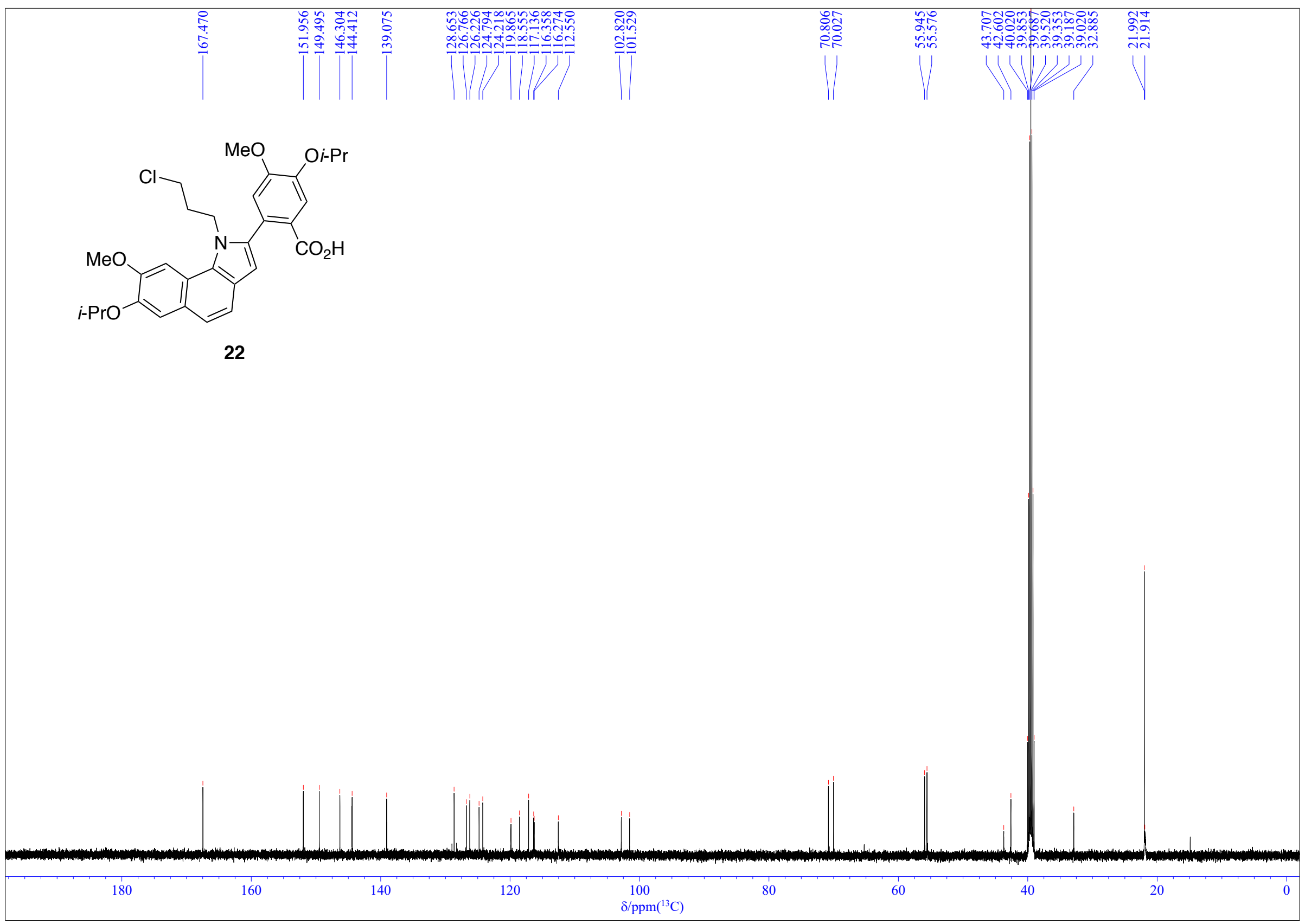

Figure S44. ${ }^{13} \mathrm{C}$ NMR spectrum of compound $22\left(126 \mathrm{MHz}\right.$, DMSO- $\left.d_{6}\right)$. 


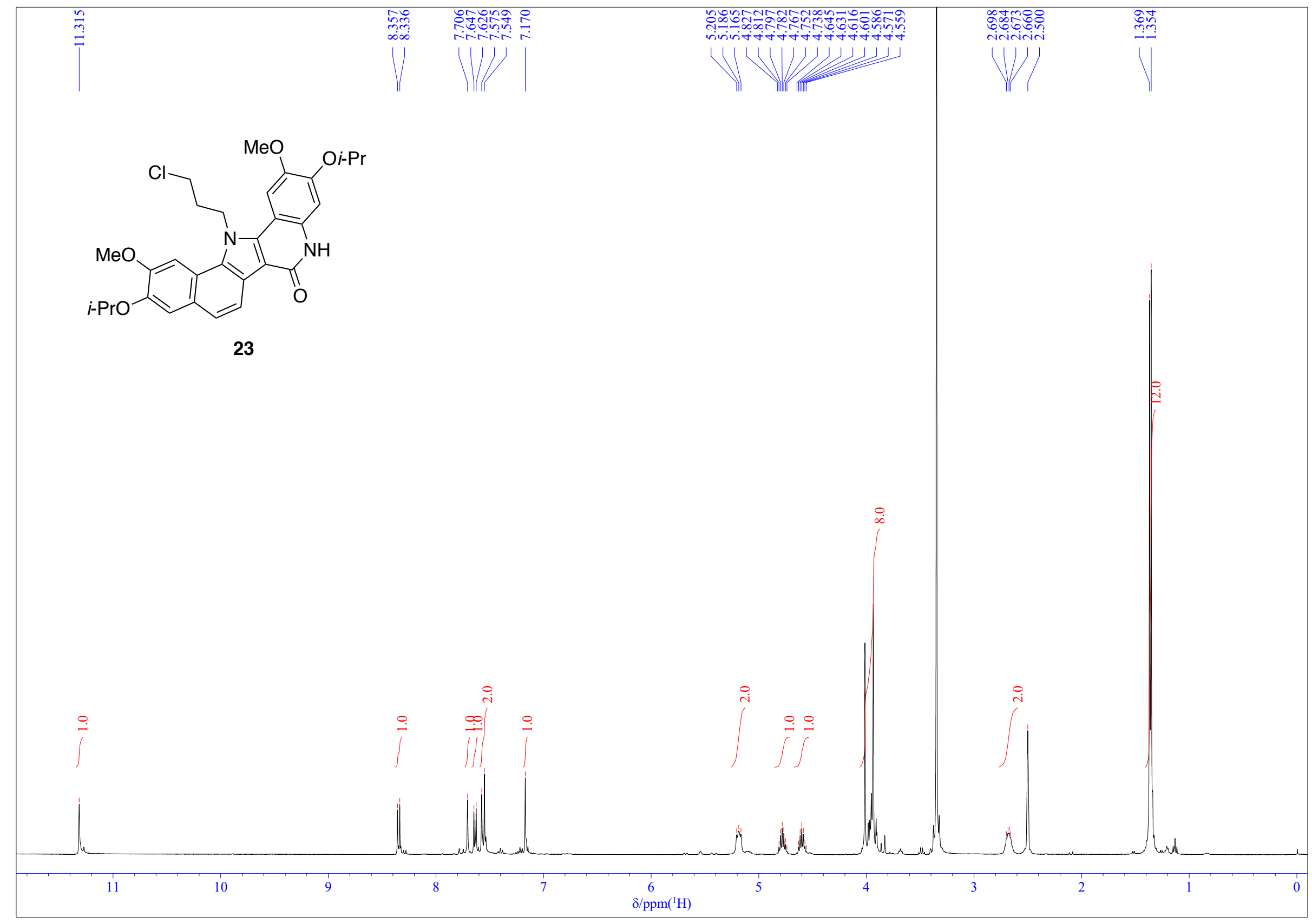

Figure S45. ${ }^{1} \mathrm{H}$ NMR spectrum of compound 23 (400 MHz, DMSO- $\left.d_{6}\right)$. 


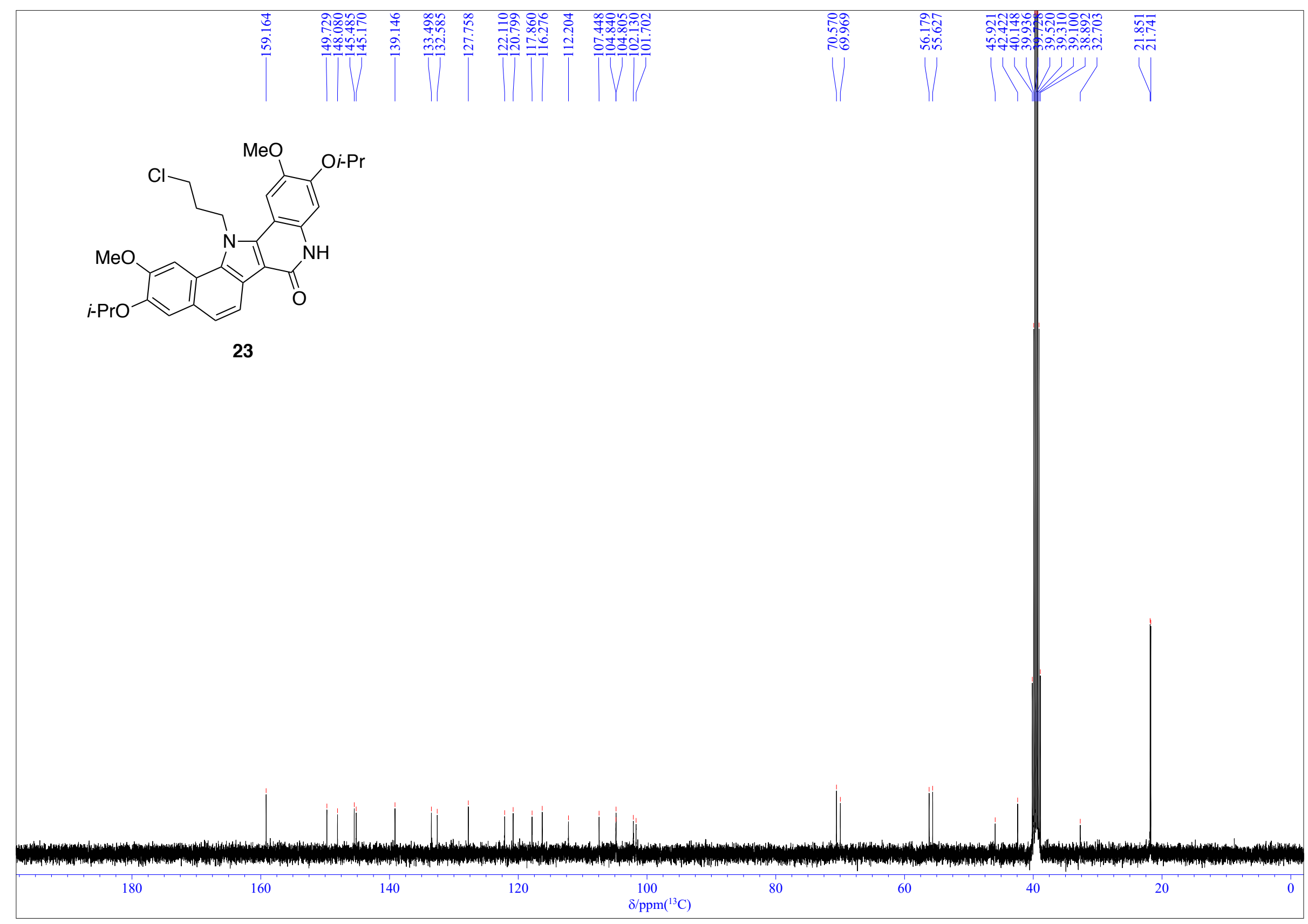

Figure S46. ${ }^{13} \mathrm{C}$ NMR spectrum of compound $23\left(100 \mathrm{MHz}\right.$, DMSO- $\left.d_{6}\right)$. 


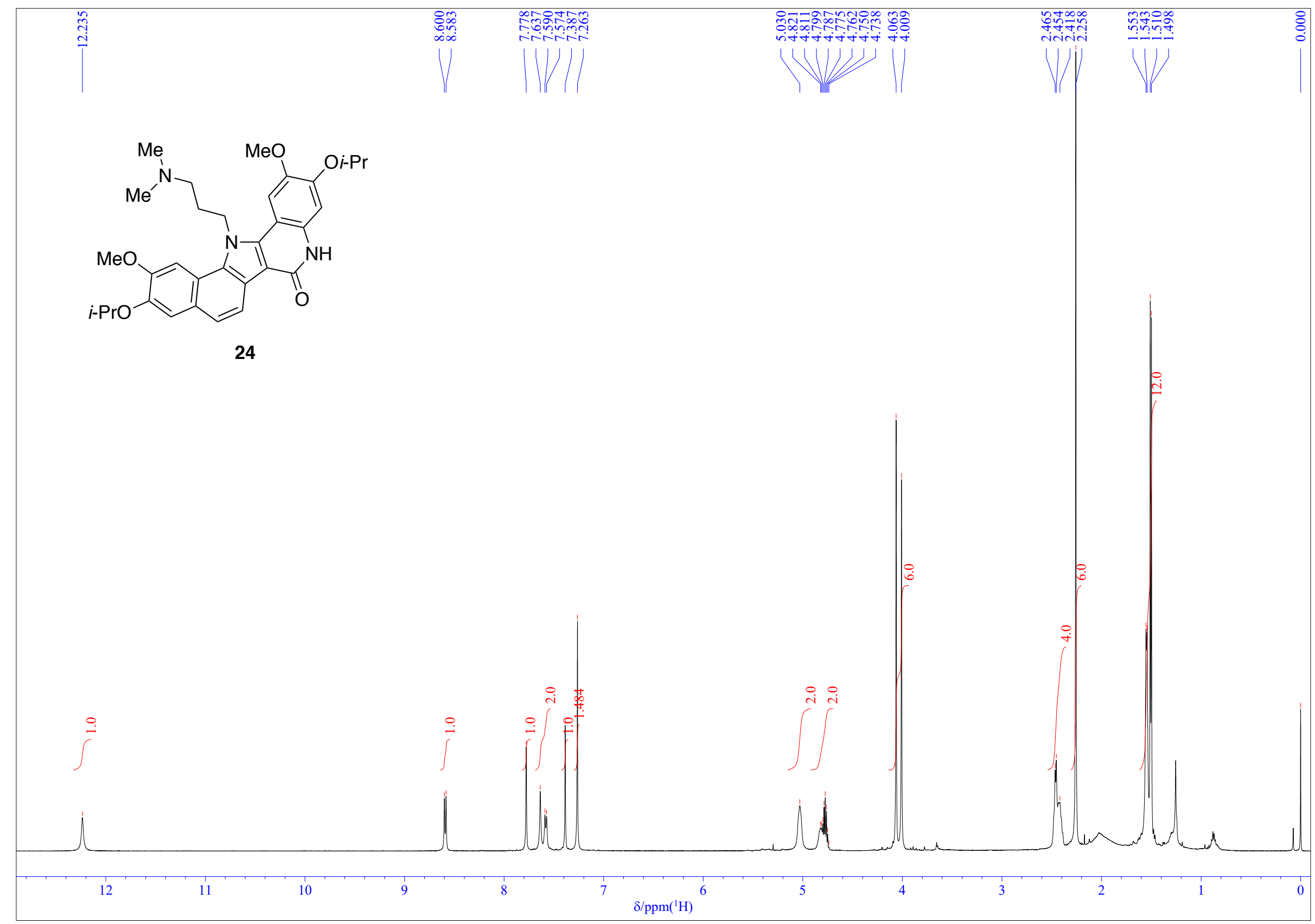

Figure S47. ${ }^{1} \mathrm{H}$ NMR spectrum of compound $24\left(500 \mathrm{MHz}, \mathrm{CDCl}_{3}\right)$. 


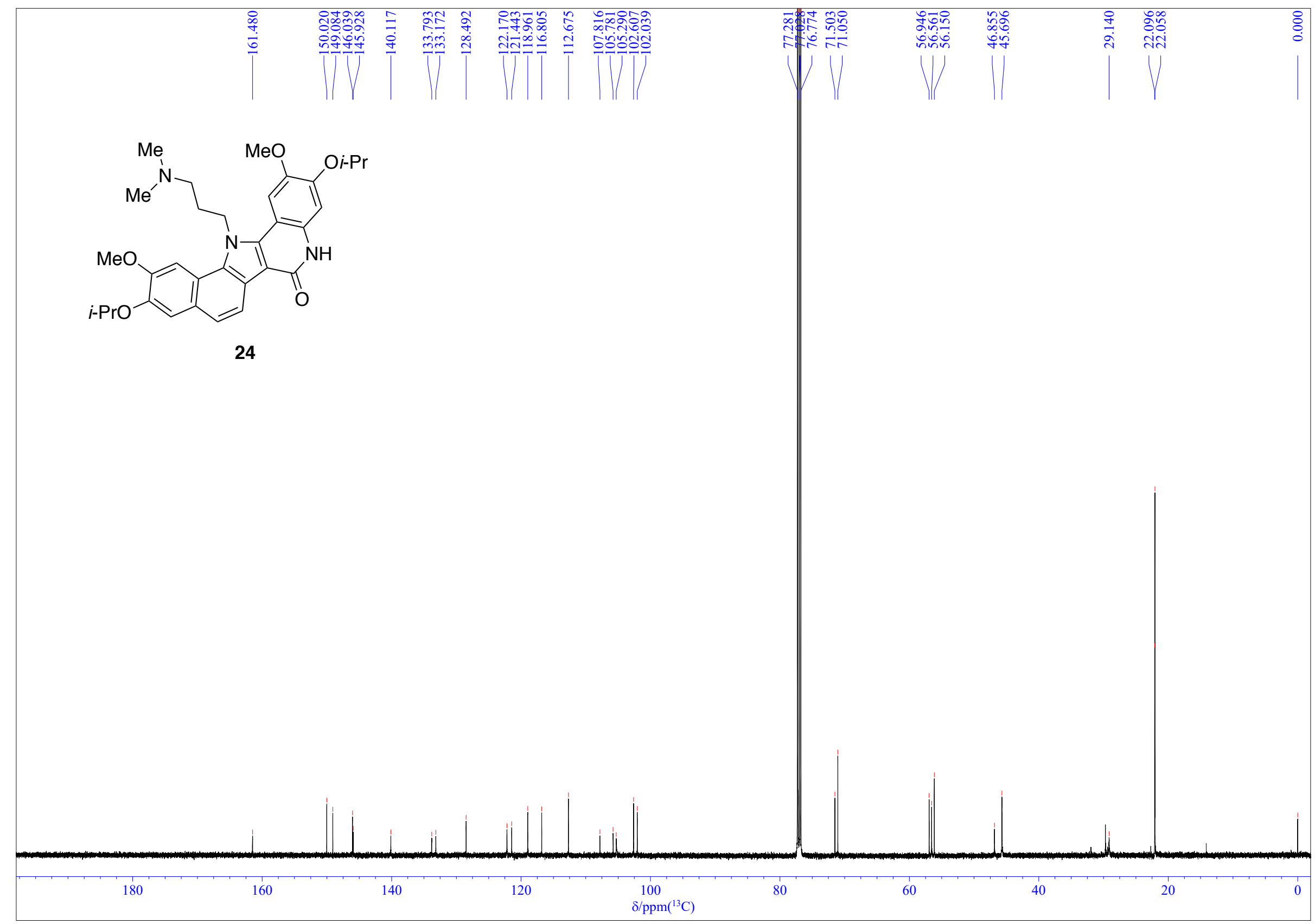

Figure S48. ${ }^{13} \mathrm{C}$ NMR spectrum of compound $24\left(126 \mathrm{MHz}, \mathrm{CDCl}_{3}\right)$. 


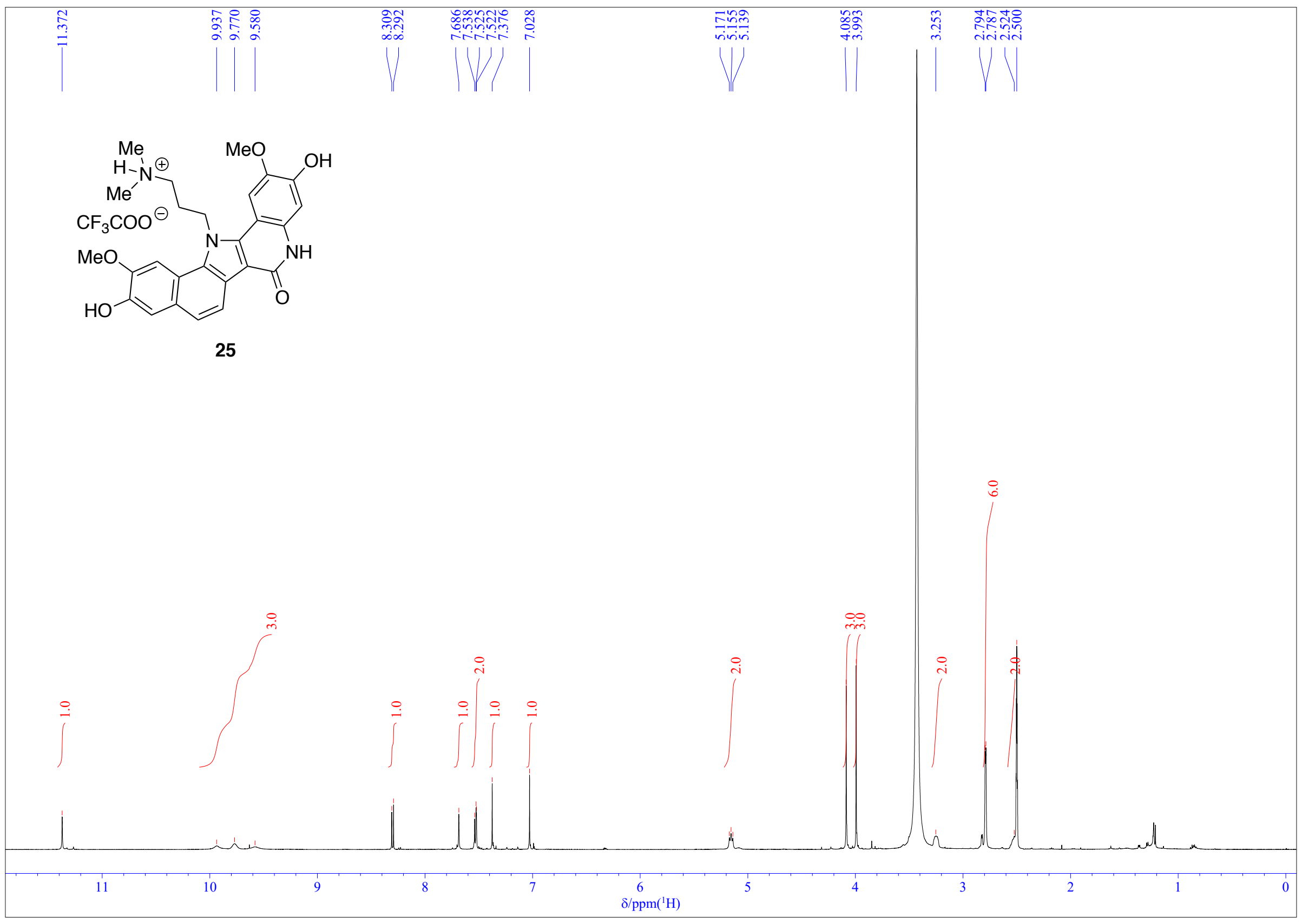

Figure S49. ${ }^{1} \mathrm{H}$ NMR spectrum of compound 25 (500 MHz, DMSO- $\left.d_{6}\right)$. 


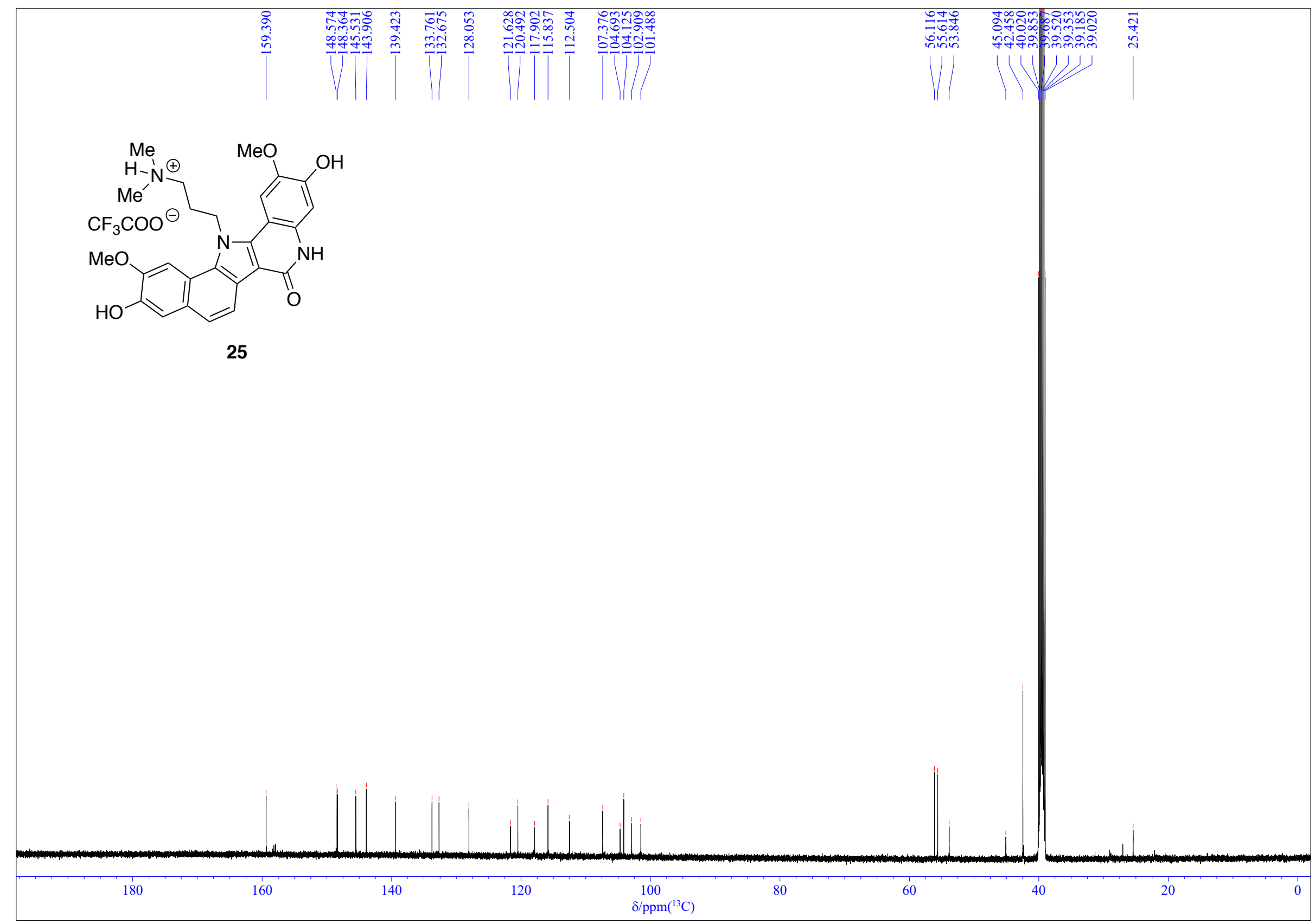

Figure S50. ${ }^{13} \mathrm{C}$ NMR spectrum of compound 25 (126 MHz, DMSO- $d_{6}$ ). 

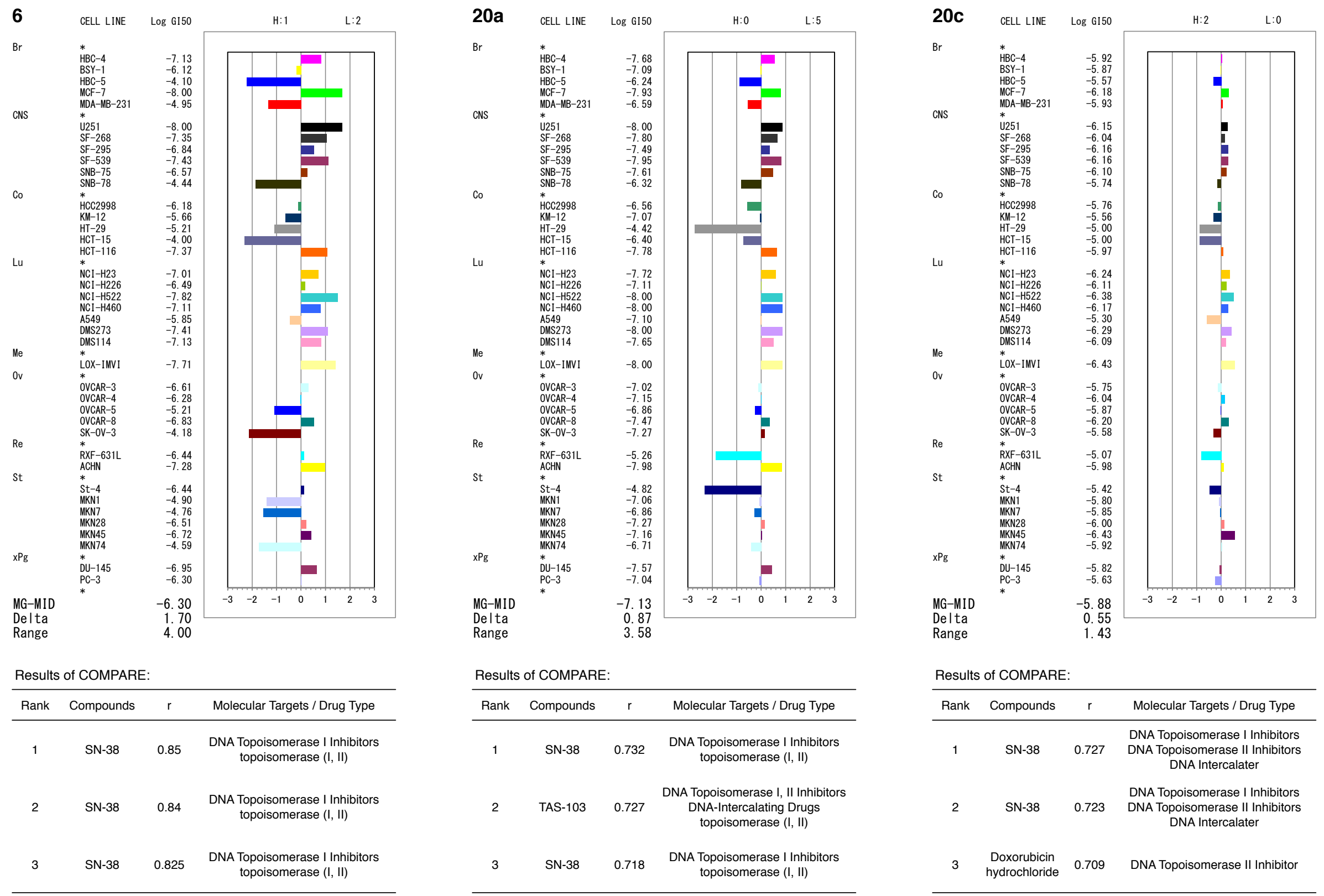

Figure S51. Chemosensitivity patterns of BIQs 6, 20a, and 20c against the JFCR39 panel and the results of COMPARE analyses. The mean graph shows the deviation of $\log \mathrm{GI}_{50}$ value of each cell line from MG-MID. The correlation coefficient $\mathrm{r}(\mathrm{r}=0-1)$ shows the similarity of the chemosensitivity pattern of the tested compound to that of the known antitumor agent in the database. 